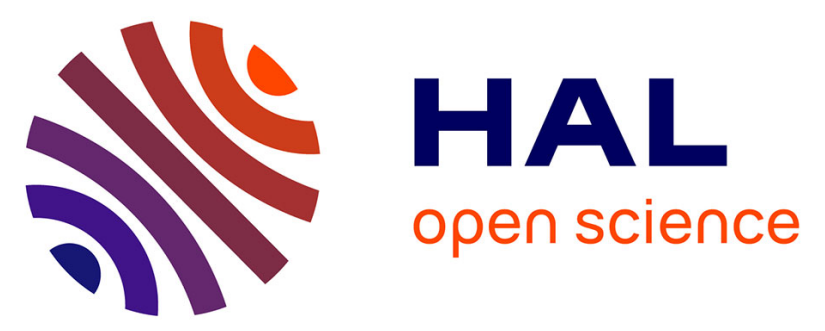

\title{
Synthesis, in vitro antiproliferative activities, and Chk1 inhibitory properties of pyrrolo[3,4-a]carbazole-1,3-diones, pyrrolo[3,4-c]carbazole-1,3-diones, and 2-aminopyridazino[3,4-a]pyrrolo[3,4-c] carbazole-1,3,4,7- tetraone
}

Elisabeth Conchon, Fabrice Anizon, Bettina Aboab, Roy Golsteyn, Stéphane Leonce, Bruno Pfeiffer, Michelle Prudhomme

\section{To cite this version:}

Elisabeth Conchon, Fabrice Anizon, Bettina Aboab, Roy Golsteyn, Stéphane Leonce, et al.. Synthesis, in vitro antiproliferative activities, and Chk1 inhibitory properties of pyrrolo[3,4-a]carbazole-1,3diones, pyrrolo[3,4-c] carbazole-1,3-diones, and 2-aminopyridazino[3,4-a]pyrrolo[3,4-c]carbazole-1,3,4,7tetraone. European Journal of Medicinal Chemistry, 2008, 43, pp.282-292. hal-00255899

\author{
HAL Id: hal-00255899 \\ https://hal.science/hal-00255899
}

Submitted on 14 Feb 2008

HAL is a multi-disciplinary open access archive for the deposit and dissemination of scientific research documents, whether they are published or not. The documents may come from teaching and research institutions in France or abroad, or from public or private research centers.
L'archive ouverte pluridisciplinaire HAL, est destinée au dépôt et à la diffusion de documents scientifiques de niveau recherche, publiés ou non, émanant des établissements d'enseignement et de recherche français ou étrangers, des laboratoires publics ou privés. 


\title{
Synthesis, in vitro antiproliferative activities, and Chk1 inhibitory properties of pyrrolo[3,4- $a$ ]carbazole-1,3-diones, pyrrolo[3,4-c]carbazole-1,3-diones, and 2-aminopyridazino[3,4-a]pyrrolo[3,4-c]carbazole-1,3,4,7-tetraone
}

\author{
Elisabeth Conchon ${ }^{\mathrm{a}}$, Fabrice Anizon ${ }^{\mathrm{a}}$, Bettina Aboab ${ }^{\mathrm{a}}$, Roy M. Golsteyn ${ }^{\mathrm{b}}$, Stéphane Léonce ${ }^{\mathrm{b}}$, \\ Bruno Pfeiffer ${ }^{\mathrm{b}}$, Michelle Prudhomme ${ }^{\mathrm{a}, *}$ \\ ${ }^{a}$ Laboratoire SEESIB, Université Blaise Pascal, UMR 6504 du CNRS, 24, avenue des Landais, 63177 Aubière, France \\ ${ }^{\mathrm{b}}$ Institut de Recherches SERVIER, Division de Recherche Cancérologie, 125 Chemin de ronde, 78290 Croissy sur Seine, France
}

\begin{abstract}
The synthesis of substituted pyrrolo[3,4- $a$ ] carbazole-1,3-diones, pyrrolo[3,4-c]carbazole-1,3-diones, and 2-aminopyridazino[3,4- $a]$ pyrrolo[3,4-c]carbazole-1,3,4,7-tetraone is reported. Their inhibitory properties toward Checkpoint 1 kinase (Chk1) have been evaluated and their in vitro antiproliferative activities toward three tumor cell lines: murine leukemia L1210, human colon carcinoma HT29 and HCT116 have been determined. From the biological results, it appears that, in contrast with the upper E heterocycle, the lower D heterocycle is not absolutely required for Chk1 inhibition. The ATP binding pocket of Chk1 seems to be adaptable to substitution of the nitrogen of the imide E heterocycle with a hydroxymethyl group, allowing the fundamental hydrogen bond with the $\mathrm{Glu}^{85}$ residue of the enzyme.
\end{abstract}

Keywords: Pyrrolo[3,4-a]carbazole-1,3-diones; 2-Amino-pyridazino[3,4-a]pyrrolo[3,4-c]carbazole-1,3,4,7-tetraone; Antitumor agents; Chk1 inhibitors

\section{Introduction}

Chk1 kinase represents a relevant target for the conception of new antitumor agents [1,2]. Chk1 plays a major role in the G2 checkpoint that is activated in response to DNA damage. In more than $50 \%$ of tumors cells, the p53 protein is mutated leading to an inactive $\mathrm{G} 1$ checkpoint. In the p53-mutated cells, only the G2 checkpoint is activated in response to DNA damage and provokes a cell cycle arrest allowing time for DNA repair [3]. Therefore, the combination of a DNA damaging agent and a Chk1 inhibitor should drive, selectively cancer cells, toward a lethal mitosis. Inhibitors of Chk1 kinase have triggered considerable interest over the past ten years $[2,4]$. Granulatimide and isogranulatimide are natural products isolated from the ascidian Didemnum granulatum [5-7]. These compounds

\footnotetext{
* Corresponding author. Tel.: +3347340 71 24; fax: +334734077 17 .

E-mail address: michelle.prudhomme@univ-bpclermont.fr (M. Prudhomme).
}

inhibit Chk1 with $\mathrm{IC}_{50}$ values of 2 and $3 \mu \mathrm{M}$ respectively [8]. Several isomers and derivatives, in which the imidazole heterocycle is conserved, have been synthesized [7-9]. Like staurosporine and UCN-01, isogranulatimide (Fig. 1) is an ATP-competitive Chk1 inhibitor $[9,10]$. In the crystal structures of Chk1 in complex with staurosporine or UCN-01 or isogranulatimide, two hydrogen bonds are observed between the E lactam or imide heterocycle and the ATP binding site of the enzyme, the first one between NH and the carbonyl oxygen of $\mathrm{Glu}^{85}$, and the second one between the oxygen of the carbonyl group on the left and the amide nitrogen of $\mathrm{Cys}^{87}$.

In the course of structure-activity relationship studies on granulatimide, we synthesized granulatimide analogues in which the imidazole moiety was replaced by an imide or pyrrole heterocycle [11-17]. Other granulatimide analogues in which the imide $\mathrm{E}$ ring was replaced by a lactam ring and the imidazole $\mathrm{D}$ heterocycle was replaced by an imide ring were also synthesized [18]. The $\mathrm{IC}_{50}$ values toward Chk1 of 


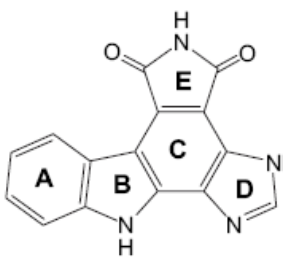

granulatimide

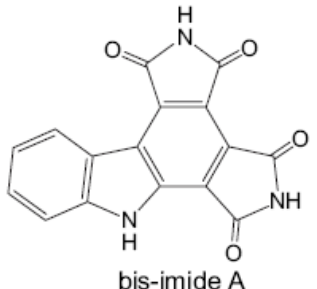<smiles>[R]c1c2c(c3[nH]c4ccccc4c3c1[R])C(=O)NC2=O</smiles>

pyrrolo[3,4-a]carbazole1,3-diones<smiles>O=C1NC(=O)c2c1c1c3ccccc3[nH]c1n1cncc21</smiles>

isogranulatimide

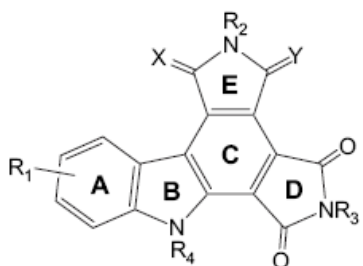

bis-imide granulatimide analogues $X=Y=O$ lactam-imides $X=\mathrm{H}_{2}, \mathrm{Y}=\mathrm{O}$ or $\mathrm{X}=\mathrm{O}, \mathrm{Y}=\mathrm{H}_{2}$

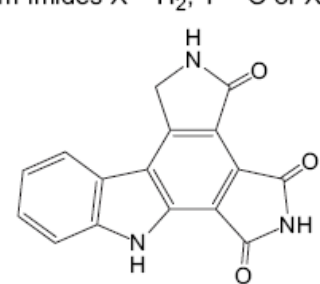

lactam-imide C

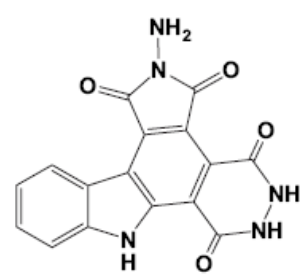

pyrrolo[3,4-c]pyridazino[3,4-a] carbazole-1,3,4,7-dione

Fig. 1. Structures of granulatimide, isogranulatimide, bis-imides and lactam-imide analogues, staurosporine and UCN-01, pyrrolo[3,4-a]carbazole-1,3-diones, pyrrolo[3,4-c]carbazole-1,3-diones, and 2-aminopyridazino[3,4- $a$ ]pyrrolo[3,4-c]carbazole-1,3,4,7-tetraone.

some bis-imides and lactam-imides are in the nanomolar range [15-18]. To investigate the role of the $C, D$, and $E$ rings, indolylpyrazolones and an indolylpyridazinedione have been synthesized [19]. The indolylpyridazinedione was found to be inactive toward Chkl and the indolylpyrazolones were poor Chk1 inhibitors, suggesting that a more rigid system is required for Chk1 inhibition. Accordingly, we have investigated the Chk 1 inhibitory capacities of compounds bearing the $\mathrm{A}, \mathrm{B}$ and $\mathrm{C}$ rings but in which the $\mathrm{D}$ or $\mathrm{E}$ heterocycles are missing. In this connection, substituted pyrrolo[3,4- $a$ ]carbazole-1,3-diones, in which the $\mathrm{E}$ upper imide heterocycle is missing and pyrrolo[3,4-c]carbazole-1,3-diones, in which the $\mathrm{D}$ imide heterocycle is missing, were synthesized. Moreover, 2-aminopyridazino[3,4-a]pyrrolo[3,4-c]carbazole-1,3,4,7-tetraone, in which the $\mathrm{D}$ heterocycle is a 6 -membered pyridazine dione ring was also synthesized (Fig. 1). The inhibitory activities of the new compounds toward Chk 1 were determined and their cytotoxicities toward three tumor cell lines: murine leukemia L1210, human colon carcinoma HT29 and HCT116 were evaluated.

\section{Results and discussion}

\subsection{Chemistry}

To obtain pyrrolo[3,4-a]carbazole-1,3-diones diversely substituted in 4 and 5 positions, compound 1 was firstly synthesized (Scheme 1). Ethyl 3-oxo-3-(1H-indol-3-yl)propionate was prepared from indole and ethyl 1-chloromalonate in the presence of $\mathrm{AlClEt}_{2}$ as previously described [19]. Reaction of ethyl 3-oxo-3-(1H-indol-3-yl)propionate with $\mathrm{NaH}$ then with $\mathrm{N}$-BOM-dibromomaleimide gave compound 1 . The nucleophilic substitution leading to the coupling of the maleimide was followed by $\mathrm{HBr}$ elimination yielding pyrrolocarbazole 1. By reaction of 1 with $\mathrm{PCl}_{5}$ in $\mathrm{DMF}$, chlorinated compound $\mathbf{2}$ was obtained in $94 \%$ yield, whereas compound $\mathbf{3}$ without the ethoxycarbonyl group was prepared from compound $\mathbf{1}$ in $96 \%$ yield via a Krapcho decarboxylation [20] by reaction with $\mathrm{LiCl}$ in DMF. Hydrogenolysis of $\mathbf{3}$ followed by aminolysis led to compound $\mathbf{4}$ in $33 \%$ yield. Hydrogenolysis of $\mathbf{1}$ using $\mathrm{Pd}(\mathrm{OH})_{2}$ as a catalyst led to compound $\mathbf{5}$ in $80 \%$ yield. Aminolysis of $\mathbf{5}$ afforded imide $\mathbf{6}$ in $30 \%$ yield.

The sequence of reactions for the synthesis of a pyrrolo[3,4-a]carbazole-1,3-dione with the ethoxycarbonyl group in the 5-position is outlined in Scheme 2. Reaction of ethyl 1-(phenylsulfonyl)indole-3-glyoxylate [21] 7 with methyl magnesium bromide provided intermediate $\mathbf{8}$ in $77 \%$ yield. Compound $\mathbf{8}$ was dehydrated in the presence of $p$-toluenesulfonic acid to give compound $\mathbf{9}$ in $95 \%$ yield. Compound $\mathbf{9}$ was isolated as two conformers. The conformers' ratio $(6: 1$ in $\mathrm{CDCl}_{3}$ ) was determined from the ${ }^{1} \mathrm{H}$ NMR spectrum on the signals of the ethylenic $\mathrm{CH}_{2}$ at 6.02 and $6.45 \mathrm{ppm}$ for the major conformer and at 6.14 and $6.26 \mathrm{ppm}$ for the minor conformer. In DMSO, the conformers' ratio (4:1) was determined on the signals of the ethylenic $\mathrm{CH}_{2}$ at 6.27 and $6.49 \mathrm{ppm}$ for the major conformer and at 6.42 and $6.56 \mathrm{ppm}$ for the minor 


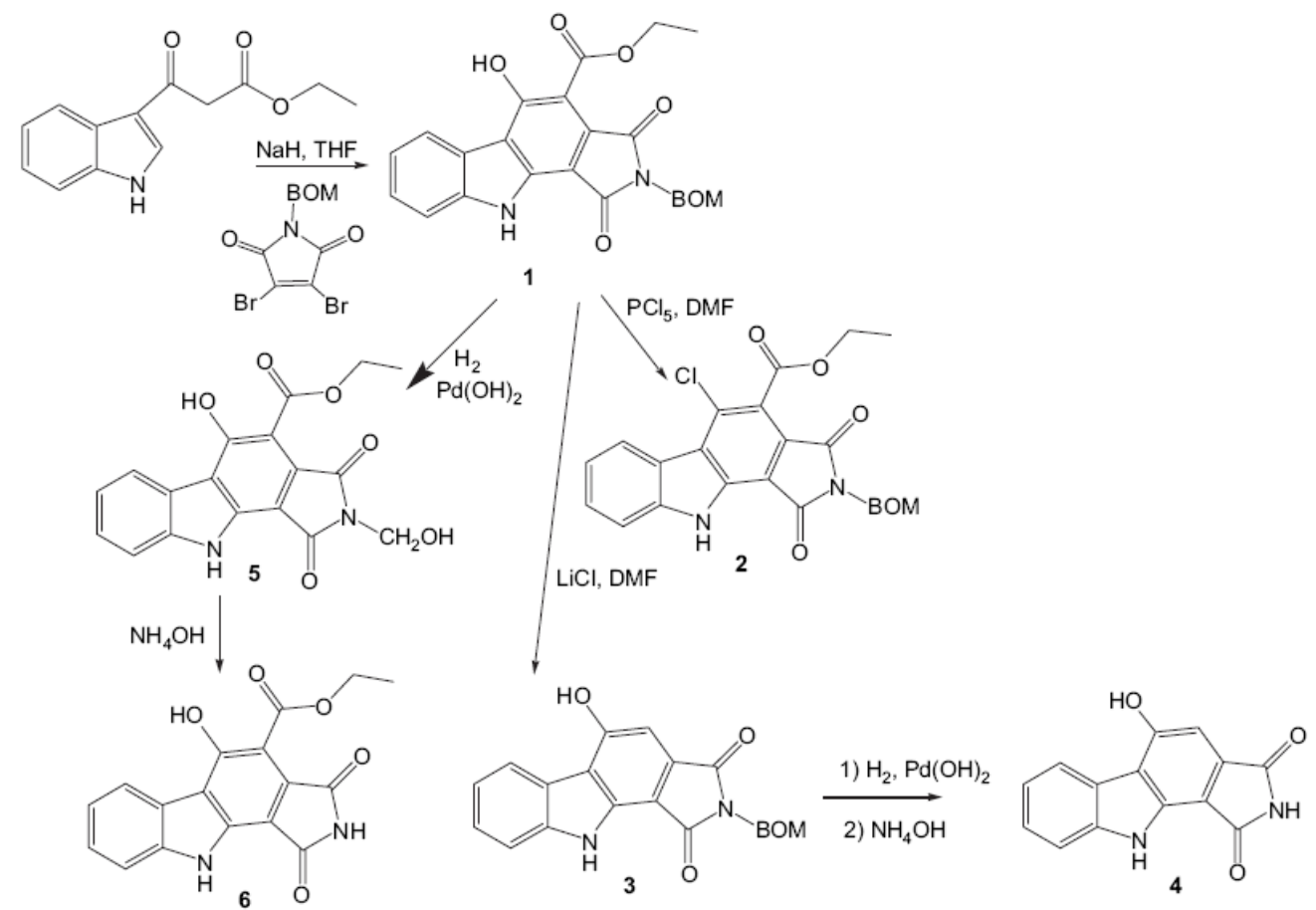

Scheme 1. Synthetic scheme for compounds $\mathbf{1}-\mathbf{6}$.

conformer. A Diels-Alder cycloaddition between compound 9 and maleimide carried out in xylene led to the indoline isomer 10 of the cycloadduct in $44 \%$ yield. The structure of the indoline isomer 10 was assigned from NMR ${ }^{1} \mathrm{H}-{ }^{1} \mathrm{H}$ COSY correlations (Fig. 2). The two protons of the methylene group at $2.11(\mathrm{~m})$ and $3.57 \mathrm{ppm}(\mathrm{dd})$ are coupled with the proton at $3.19 \mathrm{ppm}$ (ddd) which is coupled with the proton at $4.07 \mathrm{ppm}$ (dd) which is coupled with the proton at $4.42 \mathrm{ppm}$ (dd). Oxidation using DDQ led to $N$-phenylsulfonyl carbazole 11 in a poor yield $(20 \%)$. To improve the yield of the oxidation, deprotection of the indole nitrogen was carried out using tetrabutylammonium fluoride (15 equiv.) in refluxing THF. Concomitant with the removal of the phenylsulfonyl protective group, oxidation into carbazole was observed leading directly to compound $\mathbf{1 2}$ in $83 \%$ yield.

To get an insight into the influence of the D imide heterocycle, compound 13 (Scheme 3), in which this heterocycle is missing, was prepared from indolylmaleimide and ethyl acrylate, followed by oxidation of the Diels-Alder cycloadduct intermediate. The position of ethyloxycarbonyl substituent was

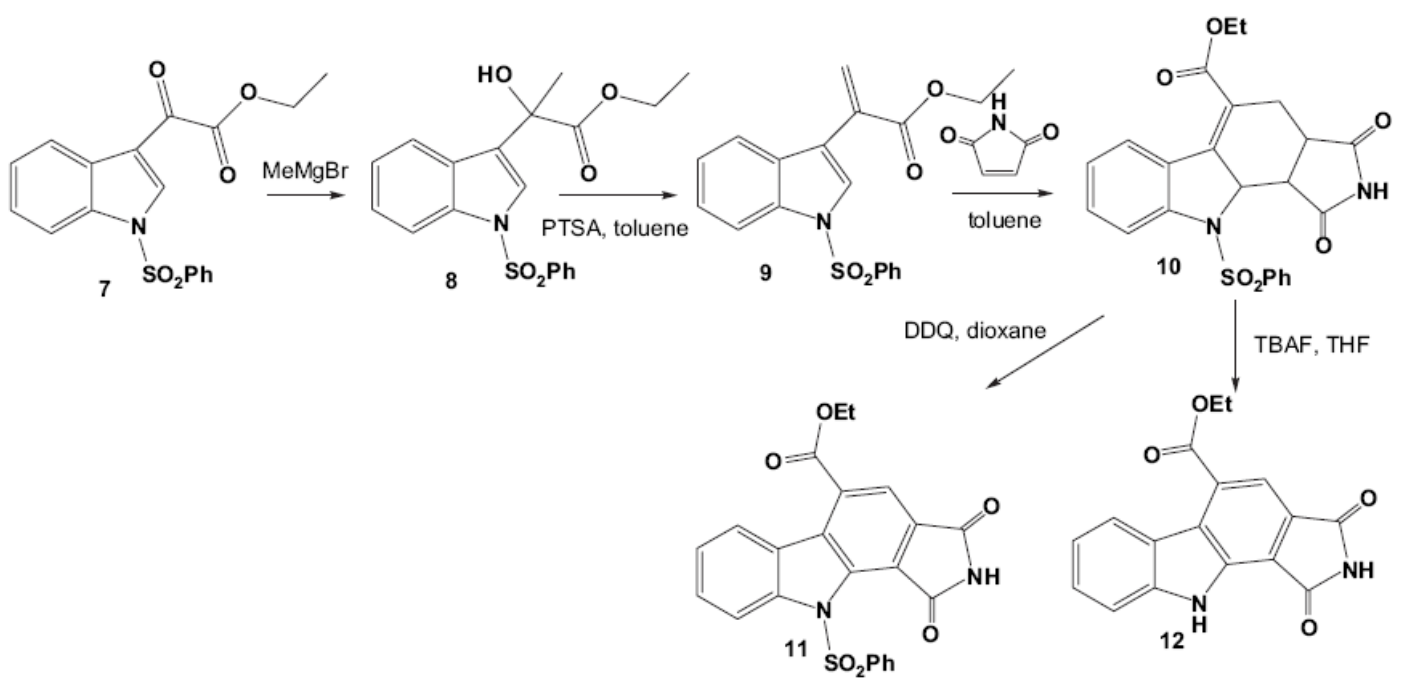

Scheme 2. Synthetic scheme for compounds 8-12. 


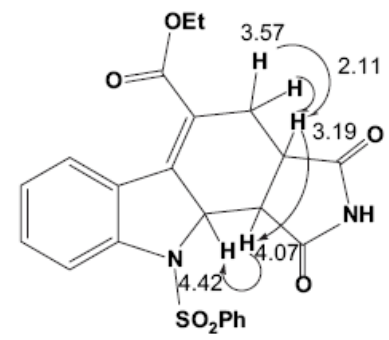

10

Fig. 2. ${ }^{1} \mathrm{H}-{ }^{1} \mathrm{H}$ COSY correlations in compound $\mathbf{1 0}$.

assigned from NMR experiments (COSY ${ }^{1} \mathrm{H}-{ }^{1} \mathrm{H}$, HSQC, and $\mathrm{HMBC}$ ). The singlet at $8.23 \mathrm{ppm}$ was coupled with the tertiary carbon at $120.2 \mathrm{ppm}$. The HMBC spectrum showed that the proton at $8.23 \mathrm{ppm}$ was coupled with two $\mathrm{C}=\mathrm{O}$ at 164.4 , and 169.3 ppm (Fig. 3).

With the aim of converting the ester function into a hydrazide function, the imide nitrogen of compound $\mathbf{1 3}$ was protected with a benzyloxymethyl substituent. Reaction of $\mathbf{1 3}$ with benzyloxymethylchloride in the presence of diisopropylethylamine as a base led to compounds 14 and 15 bearing a benzyloxymethyl and a hydroxymethyl substituent on the imide nitrogen, in $76 \%$ and $17 \%$ yields, respectively.

Finally, to obtain a compound with a pyridazinedione upper E heterocycle, with which the fundamental hydrogen bonds with the Glu ${ }^{85}$ and $\mathrm{Cys}^{87}$ in the ATP binding site of the enzyme should be conserved but with a six-membered ring heterocycle, a Diels-Alder reaction between 4-(indol-3-yl)pyridazin-3,6-dione [19] and maleimide was tried. Since the cycloaddition did not occur, 1,3,4,6-tetrahydrofuro[3,4-a]pyrrolo-[3,4-c]carbazole-1,3,4,6-tetraone 17 (Scheme 4) was prepared from 3-(3-indolyl)furane-2,5-dione [11]. A Diels-Alder cycloaddition with maleimide afforded indole 16 in $90 \%$ yield. The indole structure of compound 16 was assigned from its two exchangeable protons shifted at about $11.5 \mathrm{ppm}$ (in indolines, the $\mathrm{NH}$ proton is shifted at about $8 \mathrm{ppm}$ ). Oxidation of 16 with DDQ led to carbazole 17 in $86 \%$ yield. Reaction of compound 17 with hydrazine hydrate followed by acidification led to compounds 18 and 19 in $3 \%$ and $37 \%$ yields, respectively. Compound 19 was not obtained as the hydrochloride, probably due to the electron withdrawing effect of the maleimide. It was not surprising to isolate compound 19 from the reaction with hydrazine hydrate, because in rebeccamycin and indolocarbazole series, the amino group on the maleimide nitrogen could never be converted into a hydrochloride [22].

In rebeccamycin and indolocarbazole series, we previously observed the conversion of a maleic anhydride or a maleimide into a $\mathrm{N}$-amino-maleimide or pyridazine dione (Fig. 4) $[23,24]$. It seems that the pyridazine dione 6-membered heterocycle is favoured when the overall structure is more rigid. In compound 19, the heterocycles D and E could be inversed. Indeed, in the presence of hydrazine hydrate, the maleic anhydride of compound $\mathbf{1 7}$ could lead to a pyridazine dione whereas the $\mathrm{D}$ maleimide cycle could lead to a $\mathrm{N}$-amino maleimide $[23,25]$, but the isolation of intermediate $\mathbf{1 8}$ is in the favour of the formation of pyridazine dione as the D heterocycle. In the ${ }^{1} \mathrm{H}$ NMR spectrum of compound $\mathbf{1 8}$, the signals of the exchangeable protons are shifted at $12.29 \mathrm{ppm}$ as a broad signal $(3 \mathrm{H})$ which is in agreement with the presence of a pyridazine ring. In the ${ }^{1} \mathrm{H}$ NMR spectrum of compound 19, two exchangeable protons appear as a singlet shifted at $5.30 \mathrm{ppm}$ which is in agreement with $\mathrm{N}-\mathrm{NH}_{2}$. Three other exchangeable protons, shifted at chemical shifts $>12 \mathrm{ppm}$, correspond to the indolic $\mathrm{NH}$ and $\mathrm{NH}-\mathrm{NH}$ of the hydrazide. The isolation of compound 18 shows that the maleimide ring reacts more quickly than the maleic anhydride ring with hydrazine hydrate. Compound $\mathbf{1 8}$ should be an intermediate which in the presence of a second molecule of hydrazine hydrate would lead to compound $\mathbf{1 9}$ bearing a $N$-amino-maleimide as the E heterocycle.

\subsection{Chk1 inhibitory activities}

Unfortunately, compound 19 was highly insoluble, therefore its biological activities could not be evaluated. In the other newly synthesized structures, the D or E ring is missing. In compounds $\mathbf{5}$ and $\mathbf{1 2}$, the position of the ethyl carboxylate is inverted on the $\mathrm{C}$ ring, which should have an influence on the Chk1 inhibitory activities. The Chk 1 inhibitory properties have been evaluated and compared with those of granulatimide, isogranulatimide, bis-imide $\mathbf{A}$, lactam-imides $\mathbf{B}$ and $\mathbf{C}$
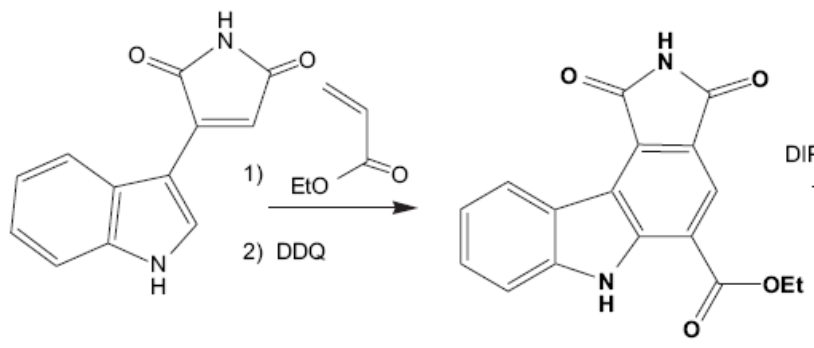

13

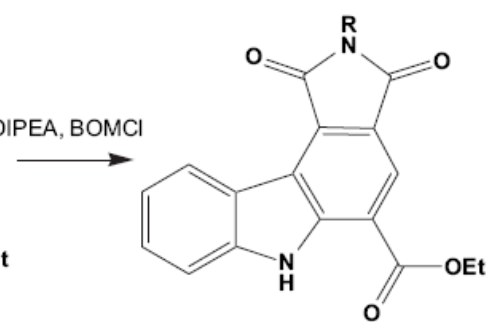

$14 \mathrm{R}=\mathrm{BOM}$

$15 \mathrm{R}=\mathrm{CH}_{2} \mathrm{OH}$ 


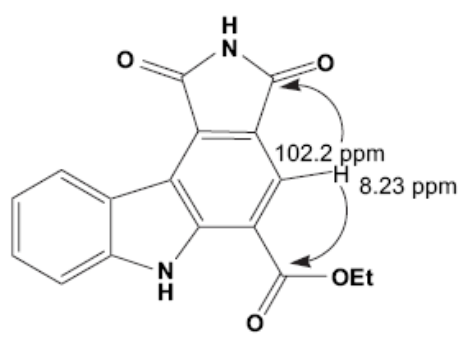

13

Fig. $3 .{ }^{13} \mathrm{C}-{ }^{1} \mathrm{H}$ correlations in compound $\mathbf{1 3}$.

shown in Fig. 1 (Table 1). The percentage of Chk1 inhibition were determined at a compound concentration of $10 \mu \mathrm{M}$. For the potent $\mathrm{Chk} 1$ inhibitors, the $\mathrm{IC}_{50}$ values were determined. Compound $\mathbf{4}$ in which the $\mathrm{E}$ ring is missing and which does not bear a carbonyl group attached to the $\mathrm{C}$ ring was a poor Chk1 inhibitor. Compounds $\mathbf{5}$ and $\mathbf{6}$ in which the $\mathrm{E}$ ring is missing and in which a carbonyl group is attached to the $\mathrm{C}$ ring at the 4-position were inactive. Compound $\mathbf{1 2}$, in which the $\mathrm{E}$ ring is missing and in which a carbonyl group is attached to the $\mathrm{C}$ ring at the 5-position, was a modest Chk1 inhibitor whereas compounds $\mathbf{5}$ and $\mathbf{6}$ do not inhibit this kinase. These results are in agreement with what observed in the lactamimide series [18]. When the E ring was a lactam, the Chk1 inhibitory activities of lactam-imides in which the carbonyl of the lactam is oriented on the left (toward the indole) were always stronger than those of lactam-imides in which the carbonyl of the lactam is oriented on the right (toward the imide) [18]. These results might be explained by the possibility of the first ones to establish the fundamental hydrogen bonds with $\mathrm{Glu}^{85}$ and $\mathrm{Cys}^{87}$ residues in the ATP binding pocket of Chk1.

Anhydride 16 was a poor Chk 1 inhibitor and anhydride 17 did not inhibit Chk1 suggesting that the hydrogen bond with
$\mathrm{Glu}^{85}$ is necessary to stabilize the molecules inside the ATP binding site. Compound 13, possessing the E imide heterocycle but lacking the D heterocycle inhibited Chk1 although the $\mathrm{IC}_{50}$ value was superior than $5 \mu \mathrm{M}$. Compound $\mathbf{1 5}$, in which the $\mathrm{D}$ heterocycle is missing but bearing a hydroxymethyl substituent on the imide nitrogen of the $\mathrm{E}$ heterocycle, was a strong Chk1 inhibitor with an $\mathrm{IC}_{50}$ value of $0.21 \mu \mathrm{M}$. This result was somewhat surprising because in the previous series, a free nitrogen at the imide $\mathrm{E}$ heterocycle was required for Chk1 inhibitory activity. Molecular modelling studies have been carried out to investigate the stabilization of compounds 13 and 15 in the ATP binding pocket of Chk1.

\subsection{Molecular modelling studies}

Molecular modelling with compounds $\mathbf{1 3}$ and $\mathbf{1 5}$ were carried out using as model the complex structure of Chk1/ staurosporine [10] downloaded from the Protein Data Bank. Interestingly, in both cases, the two fundamental hydrogen bonds were conserved between $\mathrm{Glu}^{85}$ and $\mathrm{Cys}^{87}$ residues of the enzyme and the D heterocycle. In both cases, there is a hydrogen bond between $\mathrm{NH}$ of $\mathrm{Cys}^{87}$ and the carbonyl group on the left of the D imide heterocycle. The hydrogen bond with the carbonyl of $\mathrm{Glu}^{85}$ was formed either with the imide $\mathrm{NH}$ of compound 13 (Fig. 5B) or with the hydroxy group of compound 15 (Fig. 5A). In both models, a hydrogen bond between the carbonyl of the ethyl carboxylate and the indole NH stabilized the conformation of the ethyl carboxylate. The two models were superimposed to visualize the modification of the orientation in the ATP binding site of Chk 1 (Fig. 5C). It can be observed that when compound $\mathbf{1 5}$ lies in the ATP binding pocket, a slight displacement of $\mathrm{Glu}^{85}$ allows a hydrogen bond with the hydroxy group.
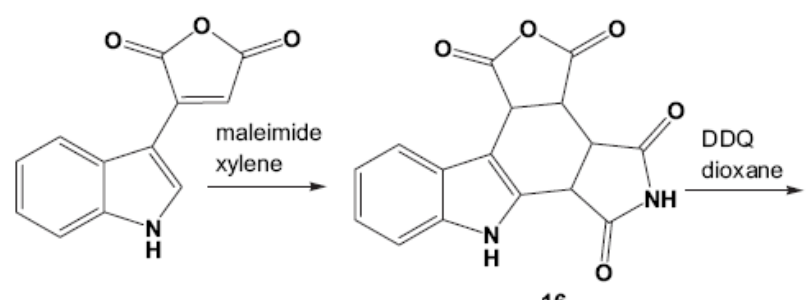<smiles>O=c1oc(=O)c2c1c1[nH]c3ccccc3c1c1c(=O)[nH]c(=O)c21</smiles>

16<smiles></smiles>

2) $\mathrm{HCl}$<smiles>O=C1OC(=O)c2c1c1c(=O)[nH][nH]c(=O)c1c1[nH]c3ccccc3c21</smiles><smiles>NN1C(=O)c2c(c3c4ccccc4[nH]c3c3c(=O)[nH][nH]c(=O)c23)C1=O</smiles>

Scheme 4. Synthetic scheme for compounds 16-19. 


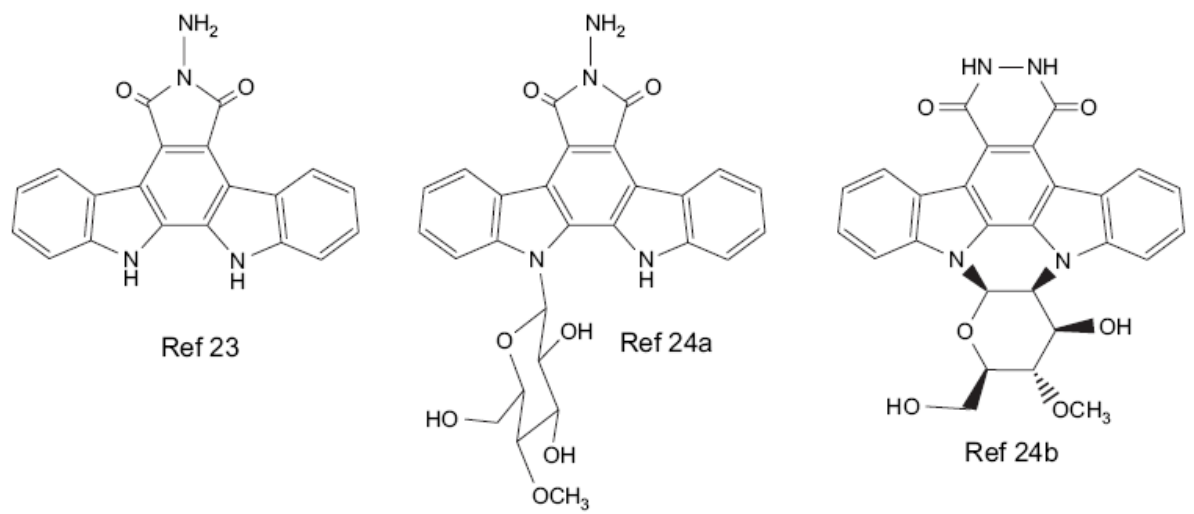

Fig. 4. $\mathrm{N}$-Amino maleimides and pyridazine heterocycles in indolocarbazole series.

\subsection{In vitro antiproliferative activities}

The in vitro antiproliferative activities against three tumor cell lines: murine leukemia L1210, human HT29 and HCT116 colon carcinoma were evaluated. The $\mathrm{IC}_{50}$ values in $\mu \mathrm{M}$ are reported in Table 1 . Compounds 4 and $\mathbf{6}$ were poorly cytotoxic toward the tumor cell lines tested. $\mathrm{The}^{\mathrm{IC}} \mathrm{I}_{50}$ values for compounds $\mathbf{1 2}, \mathbf{1 3}, \mathbf{1 5}$ and $\mathbf{1 6}$ were in the micromolar range and these compounds were not selective toward the tumor cell lines tested. Checkpoint inhibitors are not expected to be cytotoxic by themselves. They should be cytotoxic in association with DNA damaging agents. However, the cytotoxicity observed with compounds $12,13,15$ and 16 could be due to the inhibition of other kinases than Chk1. To get a first insight into the kinase selectivity, the inhibitory activity of compound 15 toward the tyrosine kinase Src has been evaluated. Compound 15 did not behave as a Src inhibitor (percentage of Src inhibition at $10 \mu \mathrm{M}: 11.5 \%$ ).

\section{Conclusion}

In conclusion, this work reports the synthesis granulatimide analogues in which the D and $\mathrm{E}$ rings are modified or absent. The biological activities of compound 19 in which the heterocycles $\mathrm{D}+\mathrm{E}$ are modified could not be evaluated due to its insolubility. Compared with bis-imide $\mathbf{A}$ and lactam-imide $\mathbf{B}$ the newly synthesized compounds $\mathbf{4 , 5 , 6}$ and $\mathbf{1 2}$ in which the E ring is missing were poor Chk1 inhibitors suggesting that this ring is required for Chk1 inhibition. Compound $\mathbf{1 5}$ in which the D ring is missing and in which the nitrogen of the E heterocycle bears a hydroxymethyl group was found to be a potent Chk1 inhibitor. At first sight, the D ring is not absolutely required. Moreover, a substitution of the imide nitrogen with a hydroxylmethyl group is compatible with Chk 1 inhibitory activity and allows hydrogen bonding with $\mathrm{Glu}^{85}$ in the ATP binding pocket of Chk1. This result is especially interesting and provides a new avenue to the design of Chk 1 inhibitors.

Table 1

Percentages of Chk1 inhibition at a drug concentration of $10 \mu \mathrm{M}$. $\mathrm{IC}_{50}$ values $(\mu \mathrm{M})$ toward Chk1

\begin{tabular}{|c|c|c|c|c|c|}
\hline Compound & $\%$ Chk 1 inhibition at $10 \mu \mathrm{M}$ & $\mathrm{IC}_{50}$ Chk1 $(\mu \mathrm{M})$ & L1210 & HCT116 & HT29 \\
\hline Granulatimide & 93.9 & 0.08 & 2.8 & 6.1 & 5.7 \\
\hline Isogranulatimide & 89.7 & 0.44 & 10 & 13 & 13.7 \\
\hline Bis-imide A & 94.4 & 0.02 & 32.7 & nd & 9.7 \\
\hline Lactam-imide B & 85.4 & 0.05 & 45.8 & 10.2 & 8.2 \\
\hline Lactam-imide C & 71.7 & 0.37 & 47.0 & 58.9 & $>100$ \\
\hline 4 & 11 & & 54.4 & 34.4 & 46.7 \\
\hline 5 & Inactive & & 10.6 & 11.5 & 31.7 \\
\hline 6 & Inactive & & 57.5 & 33.6 & 84.9 \\
\hline 12 & 45.3 & & 4.9 & 3.8 & 6.4 \\
\hline 13 & 71.7 & $>5$ & 5.8 & 2.3 & 4.0 \\
\hline 15 & 72.4 & 0.21 & 5.5 & 2.9 & 3.9 \\
\hline 16 & 10.6 & & 5.7 & nd & 6.2 \\
\hline 17 & Inactive & & 11.9 & 10.7 & 33.0 \\
\hline
\end{tabular}

In vitro antiproliferative activities against three tumor cell lines: murine leukemia L1210, human HT29 and HCT116 colon carcinoma (IC 50 MM). nd: not determined. 
A

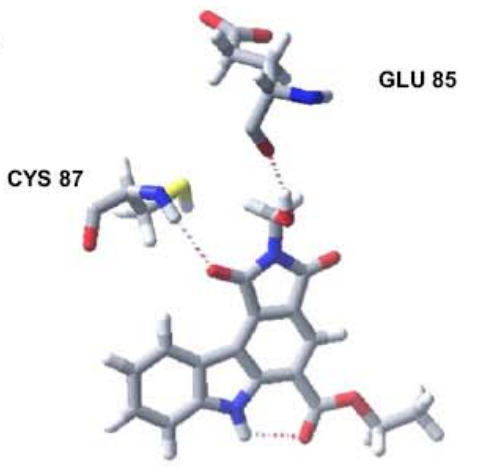

B

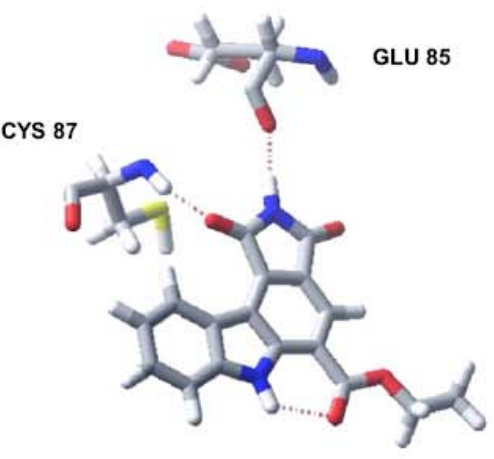

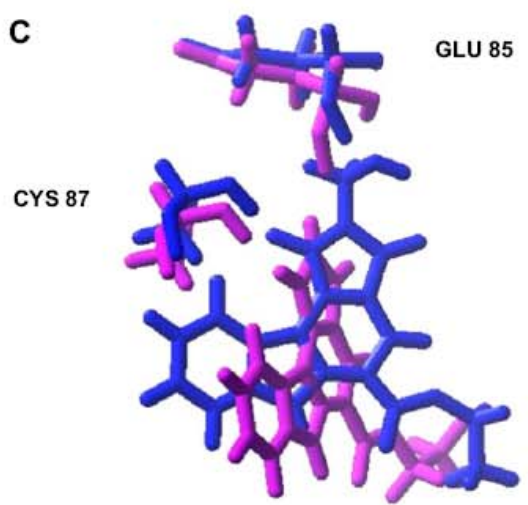

Fig. 5. Molecular modelling of compounds 13 and 15 in the ATP binding site of Chk1. 5A: compound 15, 5B: compound 13. 5C: superimposition of the two models: compounds 13 (in pink) and $\mathbf{1 5}$ (in blue). (For interpretation of the references to colours in figure legends, the reader is referred to the web version of this article.)

\section{Experimental section}

\subsection{Chemistry}

IR spectra were recorded on a Perkin-Elmer 881 spectrometer $\left(\nu\right.$ in $\left.\mathrm{cm}^{-1}\right)$. NMR spectra were performed on a Bruker AVANCE 400 (chemical shifts $\delta$ in parts per million, the following abbreviations are used: singlet (s), broad singlet (br s), doublet (d), doubled doublet (dd), triplet (t), doubled triplet (dt), multiplet (m), quadruplet (q), tertiary carbons (C tert), quaternary carbons (C quat)). Low resolution mass spectra (ESI+) and HRMS were determined on a MS Hewlett Packard engine, mass spectra $(\mathrm{FAB}+)$ were determined at CESAMO (Talence, France) on a high resolution Fisons Autospec-Q spectrometer. Chromatographic purifications were performed by flash silicagel Geduran SI 60 (Merck) $0.040-0.063 \mathrm{~mm}$ column chromatography.

\subsubsection{H-2-Benzyloxymethyl-4-ethoxycarbonyl-5-hydroxy- \\ 1,3-dihydropyrrolo[3,4-a]carbazole-1,3-dione 1}

To a solution of ethyl 3-oxo-3-( $1 H$-indol-3-yl)propionate $(250 \mathrm{mg}, 1.08 \mathrm{mmol})$ in THF $(15 \mathrm{~mL})$ was added $\mathrm{NaH}(60 \%$ in oil, $85 \mathrm{mg}, 2.16 \mathrm{mmol})$ at $0{ }^{\circ} \mathrm{C}$. The mixture was stirred at $0{ }^{\circ} \mathrm{C}$ for $30 \mathrm{~min}$, before dropwise addition to a solution of
$\mathrm{N}$-benzyloxymethyl-dibromomaleimide $(490 \mathrm{mg}, 1.31 \mathrm{mmol})$ in THF $(10 \mathrm{~mL})$. The mixture was stirred at $0{ }^{\circ} \mathrm{C}$ for $2 \mathrm{~h}$ before addition of $\mathrm{MeOH}$ to remove the excess of $\mathrm{NaH}$. After extraction with EtOAc, the organic phase was dried over $\mathrm{MgSO}_{4}$ and the solvent was removed. The solid residue was purified by flash chromatography (eluent: AcOEt/cyclohexane from 1:9 to $3: 7$ ) to give 1 (144 mg, $0.32 \mathrm{mmol}, 30 \%$ yield) as a yellow solid.

$\mathrm{Mp} 193{ }^{\circ} \mathrm{C}$. IR $(\mathrm{KBr}) \nu_{\mathrm{C}=\mathrm{O}} 1697,1725,1760 \mathrm{~cm}^{-1}, \nu_{\mathrm{NH}, \mathrm{OH}}$ $3100-3600 \mathrm{~cm}^{-1}$. HRMS (ESI + ) $[\mathrm{M}+\mathrm{Na}]^{+}$calcd for $\mathrm{C}_{25} \mathrm{H}_{20} \mathrm{~N}_{2} \mathrm{O}_{6} \mathrm{Na}$ 467.1219, found 467.1243. ${ }^{1} \mathrm{H} \quad \mathrm{NMR}$ $\left(400 \mathrm{MHz}\right.$, DMSO- $\left.d_{6}\right): 1.40(3 \mathrm{H}, \mathrm{t}, J=7.0 \mathrm{~Hz}), 4.45(2 \mathrm{H}, \mathrm{q}$, $J=7.0 \mathrm{~Hz}), 4.65(2 \mathrm{H}, \mathrm{s}), 5.10(2 \mathrm{H}, \mathrm{s}), 7.26-7.41(6 \mathrm{H}, \mathrm{m})$, $7.55(1 \mathrm{H}, \mathrm{t}, J=7.0 \mathrm{~Hz}), 7.70(1 \mathrm{H}, \mathrm{d}, J=8.0 \mathrm{~Hz}), 8.35(1 \mathrm{H}$, d, $J=8.0 \mathrm{~Hz}), 11.55(1 \mathrm{H}, \mathrm{s}, \mathrm{OH}), 12.36(1 \mathrm{H}, \mathrm{s}, \mathrm{NH}) \cdot{ }^{13} \mathrm{C}$ NMR $\left(100 \mathrm{MHz}\right.$, DMSO- $\left.d_{6}\right): 13.7\left(\mathrm{CH}_{3}\right), 61.5,66.6,70.3$ $\left(\mathrm{CH}_{2}\right), 105.5,108.6,116.7,121.0,127.9,135.2,137.7$, $141.3,155.9$ (C quat), 112.1, 120.8, 122.8, 127.0, 127.5 (3C), $128.2(2 \mathrm{C})$ (C tert), 165.5, 166.6, $166.7(\mathrm{C}=\mathrm{O})$.

4.1.2. 10H-2-Benzyloxymethyl-5-chloro-4-ethoxycarbonyl1,3-dihydropyrrolo[3,4-a]carbazole-1,3-dione 2

To a solution of 1 ( $40 \mathrm{mg}, 0.090 \mathrm{mmol})$ in DMF $(3 \mathrm{~mL})$ was added $\mathrm{PCl}_{5}(19 \mathrm{mg}, 0.090 \mathrm{mmol})$. The mixture was refluxed for $18 \mathrm{~h}$. Water was added, the precipitate was filtered 
off and washed with water to give 2 ( $39 \mathrm{mg}, 0.084 \mathrm{mmol}, 94 \%$ yield) as an orange solid.

$\mathrm{Mp}>280^{\circ} \mathrm{C}$. IR $(\mathrm{KBr}) \quad \nu_{\mathrm{C}=\mathrm{C}} 1612,1642 \mathrm{~cm}^{-1}, \nu_{\mathrm{C}=\mathrm{O}}$ $1710,1774 \mathrm{~cm}^{-1}, \nu_{\mathrm{NH}} 3380 \mathrm{~cm}^{-1}$. HRMS (ESI +$)[\mathrm{M}+\mathrm{Na}]^{+}$ calcd for $\mathrm{C}_{25} \mathrm{H}_{19} \mathrm{~N}_{2} \mathrm{O}_{5} \mathrm{ClNa} 485.0880$, found 485.0898 . ${ }^{1} \mathrm{H}$ NMR $\left(400 \mathrm{MHz}\right.$, DMSO- $\left.d_{6}\right): 1.43(3 \mathrm{H}, \mathrm{t}, J=7.0 \mathrm{~Hz}), 4.52$ $(2 \mathrm{H}, \mathrm{q}, J=7.0 \mathrm{~Hz}), 4.67(2 \mathrm{H}, \mathrm{s}), 5.15(2 \mathrm{H}, \mathrm{s}), 7.26-7.38$ $(5 \mathrm{H}, \mathrm{m}), 7.46(1 \mathrm{H}, \mathrm{t}, J=8.0 \mathrm{~Hz}), 7.72(1 \mathrm{H}, \mathrm{t}, J=7.0 \mathrm{~Hz})$, $7.81(1 \mathrm{H}, \mathrm{d}, J=8.0 \mathrm{~Hz}), 8.61(1 \mathrm{H}, \mathrm{d}, J=8.0 \mathrm{~Hz}), 12.82$ $(1 \mathrm{H}, \mathrm{s}, \mathrm{NH})$. Due to its insolubility, the ${ }^{13} \mathrm{C}$ NMR spectrum could not be recorded.

\subsubsection{H-2-Benzyloxymethyl-5-hydroxy-1,3- \\ dihydropyrrolo[3,4-a] carbazole-1,3-dione 3}

To a solution of 1 (20 mg, $0.045 \mathrm{mmol})$ in DMF $(1.5 \mathrm{~mL})$ was added $\mathrm{LiCl}(10 \mathrm{mg}, 0.22 \mathrm{mmol})$. The mixture was refluxed for $18 \mathrm{~h}$. Water was added. The precipitate was filtered off and then washed with water to give 3 ( $16 \mathrm{mg}, 0.043 \mathrm{mmol}$, $96 \%$ yield) as a yellow solid.

$\mathrm{Mp}>250{ }^{\circ} \mathrm{C}$ (decomposition). IR (KBr) $\nu_{\mathrm{C}=\mathrm{C}} 1610 \mathrm{~cm}^{-1}$, $\nu_{\mathrm{C}=\mathrm{O}} 1689,1756 \mathrm{~cm}^{-1}, \nu_{\mathrm{NH}, \mathrm{OH}} 3200-3650 \mathrm{~cm}^{-1}$. HRMS $(\mathrm{ESI}+)[\mathrm{M}+\mathrm{Na}]^{+}$calcd for $\mathrm{C}_{22} \mathrm{H}_{16} \mathrm{~N}_{2} \mathrm{O}_{4} \mathrm{Na} 395.1008$, found 395.1024. ${ }^{1} \mathrm{H}$ NMR (400 MHz, DMSO- $\left.d_{6}\right): 4.65(2 \mathrm{H}, \mathrm{s}), 5.12$ $(2 \mathrm{H}, \mathrm{s}), 7.09(1 \mathrm{H}, \mathrm{s}), 7.27-7.42(6 \mathrm{H}, \mathrm{m}), 7.51(1 \mathrm{H}, \mathrm{t}$, $J=7.5 \mathrm{~Hz}), \quad 7.66(1 \mathrm{H}, \quad \mathrm{d}, \quad J=8.0 \mathrm{~Hz}), 8.28 \quad(1 \mathrm{H}, \quad \mathrm{d}$, $J=8.0 \mathrm{~Hz}), 11.76(1 \mathrm{H}, \mathrm{s}), 12.16(1 \mathrm{H}, \mathrm{s}, \mathrm{NH}) \cdot{ }^{13} \mathrm{C}$ NMR $\left(100 \mathrm{MHz}\right.$, DMSO- $\left.d_{6}\right): 66.4,70.2\left(\mathrm{CH}_{2} \mathrm{O}\right), 100.1,111.8$, 120.4, 122.6, 126.4, 127.5 (3C), 128.2 (2C) (C tert), 104.0, $115.8,121.0,131.4,135.6,137.8,141.0,159.4$ (C quat), $167.3,168.5(\mathrm{C}=\mathrm{O})$.

\subsubsection{H,10H-5-Hydroxy-1,3-dihydropyrrolo[3,4-a]- carbazole-1,3-dione 4}

A solution of $3(40 \mathrm{mg}, 0.107 \mathrm{mmol})$ in $\mathrm{THF} / \mathrm{MeOH}$ $(4 / 1 \mathrm{~mL})$ was hydrogenated $(1 \mathrm{bar})$ in the presence of $20 \%$ $\mathrm{Pd}(\mathrm{OH})_{2} / \mathrm{C}(206 \mathrm{mg})$ for $3 \mathrm{~h}$ at room temperature. After filtration over Celite, the solvents were removed. The solid residue was dissolved into $\mathrm{THF} / \mathrm{NH}_{4} \mathrm{OH}(11 / 23 \mathrm{~mL})$ and the mixture was stirred at room temperature for $24 \mathrm{~h}$. After evaporation, AcOEt was added to the residue and the mixture was filtered off to give 4 ( $9 \mathrm{mg}, 0.036 \mathrm{mmol}, 33 \%$ yield) as a yellow solid.

$\mathrm{Mp}>280^{\circ} \mathrm{C}$. IR $(\mathrm{KBr}) \nu_{\mathrm{C}=\mathrm{C}} 1617,1636 \mathrm{~cm}^{-1}, \nu_{\mathrm{C}=\mathrm{O}}$ $1704,1746 \mathrm{~cm}^{-1}, \nu_{\mathrm{NH}, \mathrm{OH}} 3416,3479 \mathrm{~cm}^{-1}$. HRMS (FAB+) $[\mathrm{M}+\mathrm{H}]^{+}$calcd for $\mathrm{C}_{14} \mathrm{H}_{9} \mathrm{~N}_{2} \mathrm{O}_{3}$ 253.0613, found 253.0620. ${ }^{1} \mathrm{H}$ NMR (400 MHz, DMSO-d $): 6.99(1 \mathrm{H}, \mathrm{s}), 7.28(1 \mathrm{H}, \mathrm{t}$, $J=8.0 \mathrm{~Hz}), \quad 7.47 \quad(1 \mathrm{H}, \quad \mathrm{t}, \quad J=8.0 \mathrm{~Hz}), 7.62 \quad(1 \mathrm{H}, \mathrm{d}$, $J=8.0 \mathrm{~Hz}), 8.26(1 \mathrm{H}, \mathrm{d}, J=8.0 \mathrm{~Hz}), 10.88(1 \mathrm{H}, \mathrm{s}, \mathrm{NH})$, $11.56(1 \mathrm{H}, \mathrm{s}, \mathrm{NH}), 12.01(1 \mathrm{H}, \mathrm{s}, \mathrm{NH}) .{ }^{13} \mathrm{C} \mathrm{NMR}(100 \mathrm{MHz}$, DMSO- $\left.d_{6}\right)$ : $99.5,111.7,120.1,122.5,126.1$ (C tert arom), $105.2,115.4,121.1,132.8,135.3,140.9,159.0$ (C quat arom), 169.2, 170.1 (CO).

\subsubsection{H-4-Ethyloxycarbonyl-2-hydroxymethyl-}

5-hydroxy-1,3-dihydropyrrolo [3,4-a]carbazole-1,3-dione 5

A solution of compound 1 (60 mg, $0.14 \mathrm{mmol})$ in THF/ $\mathrm{MeOH}(4.0 / 1.0 \mathrm{~mL})$ was hydrogenated $(1 \mathrm{bar})$ in the presence of $\mathrm{Pd}(\mathrm{OH})_{2}(66 \mathrm{mg})$ for $5 \mathrm{~h}$ at room temperature. After filtration over Celite, the solvents were removed and the residue was purified by flash chromatography (eluent: EtOAc/cyclohexane $5: 5$ ) to give $\mathbf{5}$ (39 $\mathrm{mg}, 0.11 \mathrm{mmol}, 80 \%$ yield) as a yellow solid.

$\mathrm{Mp}>280^{\circ} \mathrm{C} . \mathrm{IR}(\mathrm{KBr}) \nu_{\mathrm{C}=\mathrm{C}} 1619,1644 \mathrm{~cm}^{-1}, \nu_{\mathrm{C}=\mathrm{O}}$ $1706,1720,1750 \mathrm{~cm}^{-1}, \nu_{\mathrm{NH}, \mathrm{OH}} 3300-3650 \mathrm{~cm}^{-1}$. HRMS $(\mathrm{ESI}+)[\mathrm{M}+\mathrm{H}]^{+}$calcd for $\mathrm{C}_{18} \mathrm{H}_{15} \mathrm{~N}_{2} \mathrm{O}_{6}$ 355.0930, found 355.0939. ${ }^{1} \mathrm{H}$ NMR (400 MHz, DMSO- $\left.d_{6}\right): 1.40(3 \mathrm{H}, \mathrm{t}$, $J=7.0 \mathrm{~Hz}), 4.44(2 \mathrm{H}, \mathrm{q}, J=7.0 \mathrm{~Hz}), 5.00(2 \mathrm{H}, \mathrm{s}), 6.36(1 \mathrm{H}$, br s, OH), $7.34(1 \mathrm{H}, \mathrm{t}, J=7.5 \mathrm{~Hz}), 7.54(1 \mathrm{H}, \mathrm{t}, J=8.0 \mathrm{~Hz})$, $7.70(1 \mathrm{H}, \mathrm{d}, J=8.0 \mathrm{~Hz}), 8.35(1 \mathrm{H}, \mathrm{d}, J=8.0 \mathrm{~Hz}), 11.58$ $(1 \mathrm{H}$, br s$), 12.30(1 \mathrm{H}, \mathrm{s}) .{ }^{13} \mathrm{C}$ NMR $\left(100 \mathrm{MHz}, \mathrm{DMSO}-d_{6}\right)$ : $13.8\left(\mathrm{CH}_{3}\right), 59.9,61.4\left(\mathrm{CH}_{2}-\mathrm{O}\right), 105.4,108.7,116.6,121.1$, $128.2,135.2,141.3,156.1$ (C quat), 112.1, 120.7, 122.8, 126.9 (C tert), 165.6, 166.5, $166.6(\mathrm{CO})$.

\subsubsection{H,10H-4-Ethoxycarbonyl-5-hydroxy-1, \\ 3-dihydropyrrolo[3,4-a]carbazole-1,3-dione 6}

To a solution of $5(28 \mathrm{mg}, 0.079 \mathrm{mmol})$ in THF $(8 \mathrm{~mL})$ was added $28 \%$ aqueous $\mathrm{NH}_{4} \mathrm{OH}(17 \mathrm{~mL})$. The mixture was stirred for $24 \mathrm{~h}$ at room temperature. After evaporation, water was added to the residue. After filtration, the solid residue was washed with water to give 6 (10 mg, $0.031 \mathrm{mmol}, 39 \%$ yield) as a yellow solid.

$\mathrm{Mp}>280^{\circ} \mathrm{C}$. IR $(\mathrm{KBr}) \nu_{\mathrm{C}=\mathrm{C}} 1619,1645 \mathrm{~cm}^{-1}, \nu_{\mathrm{C}=\mathrm{O}}$ $1662,1700,1725 \mathrm{~cm}^{-1}, \nu_{\mathrm{NH}, \mathrm{OH}} 3300-3600 \mathrm{~cm}^{-1}$. HRMS $(\mathrm{ESI}+)[\mathrm{M}+\mathrm{Na}]^{+}$calcd for $\mathrm{C}_{17} \mathrm{H}_{12} \mathrm{~N}_{2} \mathrm{O}_{5} \mathrm{Na} 347.0644$, found 347.0661. ${ }^{1} \mathrm{H}$ NMR (400 MHz, DMSO- $\left.d_{6}\right): 1.38(3 \mathrm{H}, \mathrm{t}$, $J=7.0 \mathrm{~Hz}), \quad 4.42 \quad(2 \mathrm{H}, \quad \mathrm{q}, \quad J=7.0 \mathrm{~Hz}), 7.33 \quad(1 \mathrm{H}, \quad \mathrm{dt}$, $\left.J_{1}=8.0 \mathrm{~Hz}, \quad J_{2}=1.0 \mathrm{~Hz}\right), \quad 7.53 \quad\left(1 \mathrm{H}, \quad \mathrm{dt}, \quad J_{1}=8.0 \mathrm{~Hz}\right.$, $\left.J_{2}=1.0 \mathrm{~Hz}\right), 7.68(1 \mathrm{H}, \quad \mathrm{d}, \quad J=8.0 \mathrm{~Hz}), 8.32(1 \mathrm{H}, \mathrm{d}$, $J=8.0 \mathrm{~Hz}), 11.05(1 \mathrm{H}, \mathrm{s}), 11.39(1 \mathrm{H}, \mathrm{s}), 12.24(1 \mathrm{H}, \mathrm{s}) .{ }^{13} \mathrm{C}$ NMR (100 MHz, DMSO- $\left.d_{6}\right): 13.2\left(\mathrm{CH}_{3}\right), 60.8\left(\mathrm{CH}_{2}\right), 111.5$, $120.0,122.2,126.2$ (C tert arom), 106.2, 107.6, 115.8, $120.5,128.7,134.5,140.7,155.2$ (C quat arom), 165.2, $167.8,167.9(\mathrm{CO})$.

\subsubsection{Ethyl 2-hydroxy-2-(N-phenylsulfonyl-indol-3-yl)- propanoate 8}

A $3 \mathrm{M}$ solution of $\mathrm{MeMgBr}$ in $\mathrm{Et}_{2} \mathrm{O}(0.68 \mathrm{mmol}, 249 \mu \mathrm{L})$ was added dropwise to a solution of $7(110 \mathrm{mg}, 0.31 \mathrm{mmol})$ in THF $(4 \mathrm{~mL})$. The mixture was stirred at $-78{ }^{\circ} \mathrm{C}$ for $6.5 \mathrm{~h}$. The mixture was allowed to reach room temperature, and then water was added. After extraction with EtOAc, the organic phase was dried over $\mathrm{MgSO}_{4}$. The solvent was removed and the residue was purified by flash chromatography (eluent: cyclohexane/EtOAc 7:3) to give 8 (90 $\mathrm{mg}, 0.24 \mathrm{mmol}, 77 \%$ yield) as a yellow oil.

IR ( NaCl film) $\nu_{\mathrm{C}=\mathrm{O}} 1725 \mathrm{~cm}^{-1}, \nu_{\mathrm{OH}} 3501 \mathrm{~cm}^{-1}$. HRMS $(\mathrm{ESI}+)[\mathrm{M}+\mathrm{Na}]^{+}$calcd for $\mathrm{C}_{19} \mathrm{H}_{19} \mathrm{NO}_{5} \mathrm{NaS} 396.0882$, found 396.0882. ${ }^{1} \mathrm{H}$ NMR $\left(400 \mathrm{MHz}\right.$, DMSO- $\left.d_{6}\right): 1.07(3 \mathrm{H}, \mathrm{t}$, $J=7.0 \mathrm{~Hz}), 1.78(3 \mathrm{H}, \mathrm{s}), 4.08(1 \mathrm{H}, \mathrm{q}, J=7.0 \mathrm{~Hz}), 6.14(1 \mathrm{H}$, s, OH), $7.27\left(1 \mathrm{H}, \mathrm{dt}, J_{1}=8.0 \mathrm{~Hz}, J_{2}=1.0 \mathrm{~Hz}\right), 7.37(1 \mathrm{H}, \mathrm{dt}$, $\left.J_{1}=7.5 \mathrm{~Hz}, J_{2}=1.0 \mathrm{~Hz}\right), 7.63(2 \mathrm{H}, \mathrm{t}, J=8.0 \mathrm{~Hz}), 7.71-$ $7.74(2 \mathrm{H}, \mathrm{m}), 7.75(1 \mathrm{H}, \mathrm{s}), 7.96(1 \mathrm{H}, \mathrm{d}, J=8.0 \mathrm{~Hz}), 8.03$ $(1 \mathrm{H}, \mathrm{d}, J=9.0 \mathrm{~Hz}), 8.03(1 \mathrm{H}, \mathrm{d}, J=7.0 \mathrm{~Hz}) .{ }^{13} \mathrm{C} \mathrm{NMR}$ $\left(100 \mathrm{MHz}\right.$, DMSO- $\left.d_{6}\right): 13.8,26.1\left(\mathrm{CH}_{3}\right), 60.8\left(\mathrm{CH}_{2} \mathrm{O}\right)$, 
113.1, 121.8, 123.2 (2C), 124.7, 126.7 (2C), 129.8 (2C), 134.6 (C tert), 72.1, 126.1, 128.2, 136.1 (C quat), $173.5(\mathrm{C}=\mathrm{O})$.

\subsubsection{Ethyl 2-(N-phenylsulfonyl-indol-3-yl)prop-2-enoate 9}

A solution of $\mathbf{8}(100 \mathrm{mg}, 0.27 \mathrm{mmol})$ in toluene $(4 \mathrm{~mL})$ was refluxed for $1.5 \mathrm{~h}$ in a Dean-Stark apparatus in the presence of catalytic amounts of $p$-TsOH $(5 \mathrm{mg}, 0.03 \mathrm{mmol})$. After cooling to room temperature, and extraction with EtOAc, the organic phase was washed with water and then dried over $\mathrm{MgSO}_{4}$. Compound 9, a brown oil, was isolated as a mixture of two conformers (91 mg, $0.26 \mathrm{mmol}, 95 \%$ yield).

IR $\left(\mathrm{NaCl}\right.$ film) $\nu_{\mathrm{C}=\mathrm{O}} 1723 \mathrm{~cm}^{-1}$. Mass $(\mathrm{APCI}+)[\mathrm{M}+\mathrm{H}]^{+}$ 356. ${ }^{1} \mathrm{H}$ NMR $\left(400 \mathrm{MHz}, \mathrm{CDCl}_{3}\right)$ of the major conformer: $1.24\left(3 \mathrm{H}, \quad \mathrm{t}, \quad J_{1}=7.0 \mathrm{~Hz}, \quad J_{2}=2.0 \mathrm{~Hz}\right), 4.21 \quad(2 \mathrm{H}, \quad \mathrm{q}$, $\left.J_{1}=7.0 \mathrm{~Hz}, J_{2}=2.0 \mathrm{~Hz}\right), 6.02(1 \mathrm{H}, \mathrm{s}), 6.45(1 \mathrm{H}, \mathrm{s}), 7.15$ $\left(1 \mathrm{H}, \mathrm{dt}, J_{1}=8.0 \mathrm{~Hz}, J_{2}=1.0 \mathrm{~Hz}\right), 7.23\left(1 \mathrm{H}, \mathrm{dt}, J_{1}=8.0 \mathrm{~Hz}\right.$, $\left.J_{2}=1.0 \mathrm{~Hz}\right), 7.31\left(2 \mathrm{H}, \mathrm{dt}, J_{1}=8.0 \mathrm{~Hz}, J_{2}=1.0 \mathrm{~Hz}\right), 7.39$ $\left(1 \mathrm{H}, \mathrm{dd}, J_{1}=7.5 \mathrm{~Hz}, J_{2}=2.0 \mathrm{~Hz}\right), 7.50(1 \mathrm{H}, \mathrm{d}, J=8.0 \mathrm{~Hz})$, $7.81\left(2 \mathrm{H}, \mathrm{d}, J_{1}=7.5 \mathrm{~Hz}, J_{2}=1.0 \mathrm{~Hz}\right), 7.83(1 \mathrm{H}, \mathrm{s}), 7.93$ $(1 \mathrm{H}, \mathrm{d}, J=8.0 \mathrm{~Hz}),{ }^{13} \mathrm{C} \mathrm{NMR}\left(100 \mathrm{MHz}, \mathrm{CDCl}_{3}\right)$ of the major conformer: $14.2\left(\mathrm{CH}_{3}\right), 61.3\left(\mathrm{CH}_{2} \mathrm{O}\right), 113.7,120.4,123.6$, $124.8,126.9,127.0$ (2C), 129.3 (2C), 133.9 (C tert), 126.7 $\left(=\mathrm{CH}_{2}\right), 78.6,117.9,120.2,132.7,138.1$ (C quat). The signal of the carbonyl was not observed.

\subsubsection{H-5-Ethoxycarbonyl-10-phenylsulfonyl-1,2,3, 4-tetrahydropyrrolo[3,4-a]carbazole-1,3-dione 10}

A mixture of $9(50 \mathrm{mg}, 0.14 \mathrm{mmol})$ and maleimide $(16 \mathrm{mg}$, $0.16 \mathrm{mmol})$ in toluene $(4 \mathrm{~mL})$ was refluxed for $48 \mathrm{~h}$. The solvent was removed and the residue was purified by flash chromatography (eluent: cyclohexane/EtOAc from 7:3 to 5:5) to give 10 (21 mg, $0.046 \mathrm{mmol}, 33 \%$ yield) as a pale yellow oil.

IR ( NaCl film) $\nu_{\mathrm{C}=\mathrm{O}} 1724,1782 \mathrm{~cm}^{-1}, \nu_{\mathrm{NH}} 3441 \mathrm{~cm}^{-1}$. HRMS (ESI+) $[\mathrm{M}+\mathrm{H}]^{+}$calcd for $\mathrm{C}_{23} \mathrm{H}_{21} \mathrm{~N}_{2} \mathrm{O}_{6} \mathrm{~S} 453.1120$, found 453.1132. ${ }^{1} \mathrm{H}$ NMR (400 MHz, $\left.\mathrm{CDCl}_{3}\right): 1.24(3 \mathrm{H}, \mathrm{t}$, $J=7.0 \mathrm{~Hz}), 2.11(1 \mathrm{H}, \mathrm{m}), 3.19\left(1 \mathrm{H}, \mathrm{ddd}, J_{1}=9.0 \mathrm{~Hz}\right.$, $\left.J_{2}=7.0 \mathrm{~Hz}, \quad J_{2}=1.0 \mathrm{~Hz}\right), \quad 3.57 \quad\left(1 \mathrm{H}, \quad \mathrm{dd}, \quad J_{1}=16.0 \mathrm{~Hz}\right.$, $\left.J_{2}=1.0 \mathrm{~Hz}\right), 4.07\left(1 \mathrm{H}, \mathrm{dd}, J_{1}=9.0 \mathrm{~Hz}, J_{2}=7.0 \mathrm{~Hz}\right), 4.17$ $\left(2 \mathrm{H}, \quad \mathrm{dq}, \quad J_{1}=7.0 \mathrm{~Hz}, \quad J_{2}=3.0 \mathrm{~Hz}\right), \quad 4.42 \quad(1 \mathrm{H}, \quad \mathrm{dd}$, $\left.J_{1}=7.0 \mathrm{~Hz}, J_{2}=1.0 \mathrm{~Hz}\right), 7.00(1 \mathrm{H}, \mathrm{t}, J=7.0 \mathrm{~Hz}), 7.33(1 \mathrm{H}$, $\mathrm{t}, J=8.0 \mathrm{~Hz}), 7.38(2 \mathrm{H}, \quad \mathrm{t}, \quad J=8.0 \mathrm{~Hz}), 7.50 \quad(1 \mathrm{H}, \mathrm{t}$, $J=8.0 \mathrm{~Hz}), \quad 7.71 \quad(1 \mathrm{H}, \quad \mathrm{d}, \quad J=8.0 \mathrm{~Hz}), 7.79 \quad(2 \mathrm{H}, \quad \mathrm{d}$, $J=8.0 \mathrm{~Hz}), 8.02(1 \mathrm{H}, \mathrm{s}, \mathrm{NH}), 8.45(1 \mathrm{H}, \mathrm{d}, J=8.0 \mathrm{~Hz}) .{ }^{13} \mathrm{C}$ NMR $\left(100 \mathrm{MHz}, \mathrm{CDCl}_{3}\right): 14.1\left(\mathrm{CH}_{3}\right), 27.4,61.3\left(\mathrm{CH}_{2}\right)$, $37.5,43.5,63.5(\mathrm{CH}), 60.4$ (C quat), 115.0, 124.2, 127.2 (2C), 128.4 (2C), 129.4, 132.8, 133.9 (C tert arom), 118.4, $124.6,136.7,144.6,147.2$ (C quat arom), 165.2, 173.5, $177.5(\mathrm{C}=\mathrm{O})$.

\subsubsection{H-5-Ethoxycarbonyl-10-phenylsulfonyl-1, 3-dihydro-pyrrolo[3,4-a]carbazole-1,3-dione 11}

A mixture of 10 (90 mg, $0.20 \mathrm{mmol})$ and DDQ (100 mg, $0.40 \mathrm{mmol})$ in dioxane $(6 \mathrm{~mL})$ was refluxed for three days. The solvent was removed and the residue was purified by flash chromatography (eluent: cyclohexane/EtOAc 7:3) to give $\mathbf{1 1}$ (18 mg, $0.04 \mathrm{mmol}, 20 \%$ yield) as a yellow solid.
Mp 260-261 ${ }^{\circ} \mathrm{C}$. IR (KBr) $\nu_{\mathrm{SO}_{2} \mathrm{Ph}} 1296,1380, \nu_{\mathrm{C}=\mathrm{O}} 1704$, $1724 \mathrm{~cm}^{-1}, \nu_{\mathrm{NH}} 3329-3614 \mathrm{~cm}^{-1}$. Mass (APCI+) $[\mathrm{M}+\mathrm{Na}]^{+}$ 471, $[\mathrm{M}+\mathrm{K}]^{+}$487. ${ }^{1} \mathrm{H}$ NMR $\left(400 \mathrm{MHz}, \mathrm{DMSO}-d_{6}\right): 1.43$ $(3 \mathrm{H}, \mathrm{t}, J=7.0 \mathrm{~Hz}), 4.51(2 \mathrm{H}, \mathrm{q}, J=7.0 \mathrm{~Hz}), 7.40(2 \mathrm{H}, \mathrm{t}$, $J=8.0 \mathrm{~Hz}), \quad 7.44 \quad(1 \mathrm{H}, \quad \mathrm{t}, \quad J=8.0 \mathrm{~Hz}), 7.52 \quad(2 \mathrm{H}, \mathrm{d}$, $J=8.0 \mathrm{~Hz}), \quad 7.59 \quad(1 \mathrm{H}, \quad \mathrm{t}, \quad J=7.0 \mathrm{~Hz}), \quad 7.64 \quad(1 \mathrm{H}, \quad \mathrm{t}$, $J=7.0 \mathrm{~Hz}), 8.01(1 \mathrm{H}, \mathrm{d}, J=8.0 \mathrm{~Hz}), 8.23(1 \mathrm{H}, \mathrm{s}), 8.34(1 \mathrm{H}$, $\mathrm{d}, J=8.0 \mathrm{~Hz}), 11.63(1 \mathrm{H}, \mathrm{s}, \mathrm{NH}) \cdot{ }^{13} \mathrm{C}$ NMR $(100 \mathrm{MHz}$, DMSO- $\left.d_{6}\right): 13.9\left(\mathrm{CH}_{3}\right), 62.2\left(\mathrm{CH}_{2} \mathrm{O}\right), 117.4,120.8,124.9$, 125.7, 126.8 (2C), 129.1 (2C), 130.0, 134.4 (C tert), 124.7, $124.8,130.4,132.1,132.8,134.7,135.8,141.9$ (C quat), $165.3,165.8,167.8(\mathrm{C}=\mathrm{O})$.

\subsubsection{H,10H-5-Ethoxycarbonyl-1,3-dihydropyrrolo- \\ [3,4-a] carbazole-1,3-dione 12}

A $1 \mathrm{M}$ solution of TBAF in THF $(1.40 \mathrm{~mL})$ was added dropwise to a solution of $\mathbf{1 0}(40 \mathrm{mg}, 0.09 \mathrm{mmol})$ in THF ( $4 \mathrm{~mL}$ ). The mixture was refluxed for $48 \mathrm{~h}$. The solvent was removed, water was added to the residue and the mixture was filtered off. The solid residue was washed with water to give 12 (23 mg, $0.075 \mathrm{mmol}, 83 \%$ yield) as a yellow solid.

$\mathrm{Mp}>220^{\circ} \mathrm{C} \quad$ (degradation). IR $\quad(\mathrm{KBr}) \quad \nu_{\mathrm{C}=\mathrm{O}} \quad 1704$, $1767 \mathrm{~cm}^{-1}, \nu_{\mathrm{NH}} 3355 \mathrm{~cm}^{-1}$. HRMS (ESI+) $[\mathrm{M}+\mathrm{H}]^{+}$calcd for $\mathrm{C}_{17} \mathrm{H}_{13} \mathrm{~N}_{2} \mathrm{O}_{4}$ 309.0875, found 309.0888. ${ }^{1} \mathrm{H} \quad \mathrm{NMR}$ $\left(400 \mathrm{MHz}, \mathrm{DMSO}-d_{6}\right): 1.44(3 \mathrm{H}, \mathrm{t}, J=7.0 \mathrm{~Hz}), 4.52(2 \mathrm{H}, \mathrm{q}$, $J=7.0 \mathrm{~Hz}), 7.29\left(1 \mathrm{H}, \mathrm{dt}, J_{1}=8.0 \mathrm{~Hz}, J_{2}=1.0 \mathrm{~Hz}\right), 7.59$ $\left(1 \mathrm{H}, \mathrm{dt}, J_{1}=8.0 \mathrm{~Hz}, J_{2}=1.0 \mathrm{~Hz}\right), 7.72(1 \mathrm{H}, \mathrm{d}, J=8.0 \mathrm{~Hz})$, $7.97(1 \mathrm{H}, \mathrm{s}), 8.64(1 \mathrm{H}, \mathrm{d}, J=8.0 \mathrm{~Hz}), 11.42(1 \mathrm{H}, \mathrm{s}, \mathrm{NH})$, $12.48(1 \mathrm{H}, \mathrm{s}, \mathrm{NH}),{ }^{13} \mathrm{C}$ NMR $\left(100 \mathrm{MHz}, \mathrm{DMSO}-d_{6}\right): 14.0$ $\left(\mathrm{CH}_{3}\right), 61.7\left(\mathrm{CH}_{2}\right), 112.4,114.1,120.3,124.9,128.4(\mathrm{C}$ tert arom), 116.2, 119.7, 127.2, 128.7, 129.0, 133.9, 143.3 (C quat arom $), 166.3,168.9,169.3(\mathrm{C}=\mathrm{O})$.

\subsubsection{H,6H-5-Ethoxycarbonyl-1,3-dihydropyrrolo- \\ [3,4-c] carbazole-1,3-dione 13}

A mixture of 3-(indol-3-yl)maleimide ( $250 \mathrm{mg}, 1.18 \mathrm{mmol}$ ) and ethyl acrylate $(16.6 \mathrm{mmol}, 1.75 \mathrm{~mL})$ in toluene $(25 \mathrm{~mL})$ was refluxed for $36 \mathrm{~h}$. After evaporation, the solid residue was purified by flash chromatography (eluent: EtOAc/cyclohexane 6:4) to give the Diels-Alder cycloadduct as a mixture of isomers (orange solid, $258 \mathrm{mg}, 0.83 \mathrm{mmol}, 70 \%$ yield).

The mixture of isomers $(140 \mathrm{mg}, 0.45 \mathrm{mmol})$ and DDQ (224 $\mathrm{mg}, 0.90 \mathrm{mmol})$ in dioxane $(15 \mathrm{~mL})$ was refluxed for $24 \mathrm{~h}$. After filtration, the filtrate was evaporated and the residue was purified by flash chromatography (eluent: cyclohexane/EtOAc 5:5) to give 13 (88 mg, $0.28 \mathrm{mmol}, 64 \%$ yield) as a yellow solid.

$\mathrm{Mp}>300^{\circ} \mathrm{C}$. IR $(\mathrm{KBr}) \nu_{\mathrm{C}=\mathrm{O}} 1686,1716,1765 \mathrm{~cm}^{-1}, \nu_{\mathrm{N}-\mathrm{H}}$ $3236,3398 \mathrm{~cm}^{-1}$. HRMS (ESI+) $[\mathrm{M}+\mathrm{H}]^{+}$calcd for $\mathrm{C}_{17} \mathrm{H}_{13} \mathrm{~N}_{2} \mathrm{O}_{4}$ 309.0875, found 309.0888. ${ }^{1} \mathrm{H}$ NMR (400 MHz, DMSO): $1.48(3 \mathrm{H}, \mathrm{t}, J=7.0 \mathrm{~Hz}), 4.52(2 \mathrm{H}, \mathrm{q}, J=7.0 \mathrm{~Hz})$, $7.39\left(1 \mathrm{H}, \quad \mathrm{dt}, J_{1}=8.0 \mathrm{~Hz}, J_{2}=0.5 \mathrm{~Hz}\right), 7.63(1 \mathrm{H}, \mathrm{dt}$, $\left.J_{1}=8.0 \mathrm{~Hz}, J_{2}=1.0 \mathrm{~Hz}\right), 7.85(1 \mathrm{H}, \mathrm{d}, J=8.0 \mathrm{~Hz}), 8.23(1 \mathrm{H}$, s), $8.85(1 \mathrm{H}, \mathrm{d}, J=8.0 \mathrm{~Hz}), 11.45(1 \mathrm{H}, \mathrm{s}, \mathrm{NH}), 12.05(1 \mathrm{H}, \mathrm{s}$, $\mathrm{NH}) .{ }^{13} \mathrm{C}$ NMR (100 MHz, DMSO): $14.2\left(\mathrm{CH}_{3}\right), 61.3\left(\mathrm{CH}_{2}\right)$, $112.8,120.2,121.0,124.6,128.7$ (C tert), 114.7, 119.4, 
$120.6,122.7,129.7,142.1,143.0$ (C quat), 164.4, 169.3, 169.4 $(\mathrm{C}=\mathrm{O})$.

\subsubsection{H-2-N-Benzyloxymethyl-5-ethoxycarbonyl- pyrrolo[3,4-c]carbazole-1,3-dione 14 and $6 \mathrm{H}-2$ - \\ $\mathrm{N}$-hydroxymethyl-5-ethoxycarbonyl-pyrrolo- [3,4-c]carbazole-1,3-dione 15}

To a mixture of $13(50 \mathrm{mg}, 0.16 \mathrm{mmol})$ in acetone $(1 \mathrm{~mL})$ was added diisopropylethylamine $(70 \mu \mathrm{L}, 0.40 \mathrm{mmol})$. The mixture was stirred for $15 \mathrm{~min}$ at room temperature before dropwise addition of benzyloxymethylchloride $(45 \mu \mathrm{L}$, $0.32 \mathrm{mmol})$. The mixture was stirred at room temperature for $1 \mathrm{~h}$, and then water was added. After extraction with EtOAc, the organic phase was dried over $\mathrm{MgSO}_{4}$, the solvent was removed and the residue was purified by flash chromatography (eluent: EtOAc/cyclohexane from 3:7 to 1:0). Two compounds were isolated: $14(52 \mathrm{mg}, 0.12 \mathrm{mmol}, 76 \%$ yield) and 15 ( $9 \mathrm{mg}, 0.028 \mathrm{mmol}, 17 \%$ yield) as yellow solids.

4.1.13.1. Compound 14. Mp $153^{\circ} \mathrm{C}$. IR $(\mathrm{KBr}) \quad \nu_{\mathrm{C}=\mathrm{C}}$ $1607 \mathrm{~cm}^{-1}, \nu_{\mathrm{C}=\mathrm{O}} 1698,1708,1761 \mathrm{~cm}^{-1}, \nu_{\mathrm{NH}} 3355 \mathrm{~cm}^{-1}$. HRMS (ESI + ) $[\mathrm{M}+\mathrm{Na}]^{+}$calcd for $\mathrm{C}_{25} \mathrm{H}_{20} \mathrm{~N}_{2} \mathrm{O}_{5} \mathrm{Na}$ 451.1270, found 451.1284. ${ }^{1} \mathrm{H}$ NMR (400 MHz, DMSO- $d_{6}$ ): $1.50(3 \mathrm{H}, \mathrm{t}, J=7.0 \mathrm{~Hz}), 4.56(2 \mathrm{H}, \mathrm{q}, J=7.0 \mathrm{~Hz}), 4.69$ $(2 \mathrm{H}, \mathrm{s}), 5.21(2 \mathrm{H}, \mathrm{s}), 7.24-7.40(5 \mathrm{H}, \mathrm{m}), 7.45(1 \mathrm{H}, \mathrm{t}$, $J=7.5 \mathrm{~Hz}), \quad 7.68 \quad(1 \mathrm{H}, \quad \mathrm{t}, \quad J=8.0 \mathrm{~Hz}), \quad 7.91 \quad(1 \mathrm{H}, \quad \mathrm{d}$, $J=8.0 \mathrm{~Hz}), \quad 8.36 \quad(1 \mathrm{H}, \quad \mathrm{d}, \quad J=2.0 \mathrm{~Hz}), \quad 8.91 \quad(1 \mathrm{H}, \quad \mathrm{d}$, $J=8.0 \mathrm{~Hz}), 12.21(1 \mathrm{H}, \mathrm{s}) .{ }^{13} \mathrm{C}$ NMR $\left(100 \mathrm{MHz}, \mathrm{DMSO}-d_{6}\right)$ : $14.2\left(\mathrm{CH}_{3}\right), 61.5,66.9,70.5\left(\mathrm{CH}_{2} \mathrm{O}\right), 113.0,120.7,121.2$, 124.6, 127.5 (2C), 128.2 (2C), 129.1 (C tert), 115.2, 119.3, 121.0, 121.4, 128.4, 137.7, 142.3, 143.2 (C quat), 164.8, $167.8,167.9(\mathrm{C}=\mathrm{O})$.

4.1.13.2. Compound 15. $\mathrm{Mp}>230^{\circ} \mathrm{C}$ (decomposition). IR $(\mathrm{KBr}) \nu_{\mathrm{C}=\mathrm{C}} 1608 \mathrm{~cm}^{-1}, \nu_{\mathrm{C}=\mathrm{O}} 1687,1708,1763 \mathrm{~cm}^{-1}, \nu_{\mathrm{NH}, \mathrm{OH}}$ $3362,3439 \mathrm{~cm}^{-1}$. HRMS (ESI+) $[\mathrm{M}+\mathrm{Na}]^{+}$calcd for $\mathrm{C}_{18} \mathrm{H}_{14} \mathrm{~N}_{2} \mathrm{O}_{5} \mathrm{Na} 361.0800$, found 361.0805. ${ }^{1} \mathrm{H} \quad \mathrm{NMR}$ $\left(400 \mathrm{MHz}, \mathrm{DMSO}-d_{6}\right): 1.49(3 \mathrm{H}, \mathrm{t}, J=7.0 \mathrm{~Hz}), 4.53(2 \mathrm{H}, \mathrm{q}$, $J=7.0 \mathrm{~Hz}), \quad 5.03 \quad(2 \mathrm{H}, \quad \mathrm{d}, \quad J=7.0 \mathrm{~Hz}), 6.45 \quad(1 \mathrm{H}, \quad \mathrm{t}$, $J=7.0 \mathrm{~Hz}, \mathrm{OH}), 7.40(1 \mathrm{H}, \mathrm{t}, J=7.5 \mathrm{~Hz}), 7.64(1 \mathrm{H}, \mathrm{t}$, $J=7.5 \mathrm{~Hz}), 7.86(1 \mathrm{H}, \mathrm{d}, J=8.0 \mathrm{~Hz}), 8.23(1 \mathrm{H}, \mathrm{s}), 8.82(1 \mathrm{H}$, d, $J=8.0 \mathrm{~Hz}), 12.09(1 \mathrm{H}, \mathrm{s}, \mathrm{NH}) \cdot{ }^{13} \mathrm{C}$ NMR $(100 \mathrm{MHz}$, DMSO- $\left.d_{6}\right): 14.1\left(\mathrm{CH}_{3}\right), 60.1,61.4\left(\mathrm{CH}_{2} \mathrm{O}\right), 112.9,120.4$, 121.1, 124.4, 128.9 (C tert), 115.0, 119.2, 120.8, 121.3, 128.3, 124.2, 143.1 (C quat), 164.7, 167.3, $167.4(\mathrm{C}=\mathrm{O})$.

\subsubsection{4. $5 H, 7 H-1,3,3 a, 3 b, 4,6,6 a, 11 c$-Octahydrofuro-} [3,4-c]pyrrolo[3,4-a]carbazol-1,3,4,6-tetraone 16

A solution of 3-(indol-3-yl)furane-2,5-dione $(150 \mathrm{mg}$, $0.70 \mathrm{mmol}$ ) and maleimide $(82 \mathrm{mg}, 0.84 \mathrm{mmol})$ in xylene $(15 \mathrm{~mL})$ was refluxed for five days. After filtration, the solid residue was washed with water and dried to give 16 (195 mg, $0.63 \mathrm{mmol}, 90 \%$ yield) as an orange solid.

Mp $220-222^{\circ} \mathrm{C}$. IR $(\mathrm{KBr}) \nu_{\mathrm{C}=\mathrm{O}} 1719,1782 \mathrm{~cm}^{-1}, \nu_{\mathrm{NH}}$ $3411 \mathrm{~cm}^{-1}$. ${ }^{1} \mathrm{H}$ NMR (400 MHz, DMSO- $\left.d_{6}\right): 4.03(1 \mathrm{H}, \mathrm{t}$, $J=7.5 \mathrm{~Hz}), \quad 4.21 \quad(1 \mathrm{H}, \quad \mathrm{t}, \quad J=8.0 \mathrm{~Hz}), 4.34 \quad(1 \mathrm{H}, \quad \mathrm{d}$, $J=7.5 \mathrm{~Hz}), 4.78(1 \mathrm{H}, \mathrm{d}, J=8.0 \mathrm{~Hz}), 7.06(1 \mathrm{H}, \mathrm{m}), 7.15$
$(1 \mathrm{H}, \mathrm{t}, J=8.0 \mathrm{~Hz}), 7.42(1 \mathrm{H}, \mathrm{d}, J=8.0 \mathrm{~Hz}), 7.64(1 \mathrm{H}, \mathrm{d}$, $J=8.0 \mathrm{~Hz}), 11.44(1 \mathrm{H}, \mathrm{s}, \mathrm{NH}), 11.54(1 \mathrm{H}, \mathrm{s}, \mathrm{NH}),{ }^{13} \mathrm{C}$ NMR $\left(100 \mathrm{MHz}\right.$, DMSO- $\left.d_{6}\right): 39.3,40.2,40.5$ (2C) $(\mathrm{CH})$, $100.7,125.2,128.2,137.0$ (C quat), 111.7, 119.2, 119.5, 122.2 (C tert), 170.4, 171.2, 175.6, $177.2(\mathrm{C}=\mathrm{O})$.

\subsubsection{H,7H-1,3,4,6-Tetrahydrofuro[3,4-c]pyrrolo-}

[3,4-a]carbazol-1,3,4,6-tetraone 17

A solution of anhydride 16 (196 mg, $0.63 \mathrm{mmol})$ and DDQ $(575 \mathrm{mg}, 1.39 \mathrm{mmol})$ in dioxane $(10 \mathrm{~mL})$ was refluxed for three days. After removal of the solvent, water was added to the residue. The mixture was filtered off and the solid residue was washed with water and EtOAc to give 17 (166 mg, $0.54 \mathrm{mmol}, 86 \%$ yield) as a yellow solid.

$\mathrm{Mp}>300{ }^{\circ} \mathrm{C}$. IR (KBr) $\nu_{\mathrm{C}=\mathrm{O}} 1701,1776,1847 \mathrm{~cm}^{-1}, \nu_{\mathrm{NH}}$ $3247,3368 \mathrm{~cm}^{-1}$. HRMS (ESI+) $[\mathrm{M}+\mathrm{H}]^{+}$calcd for $\mathrm{C}_{16} \mathrm{H}_{7} \mathrm{~N}_{2} \mathrm{O}_{5}$ 307.0355, found 307.0360. ${ }^{1} \mathrm{H} \mathrm{NMR}(400 \mathrm{MHz}$, DMSO- $\left.d_{6}\right): 7.51(1 \mathrm{H}, \mathrm{t}, J=7.0 \mathrm{~Hz}), 7.75(1 \mathrm{H}, \mathrm{t}, J=7.0 \mathrm{~Hz})$, $7.82(1 \mathrm{H}, \mathrm{d}, J=7.5 \mathrm{~Hz}), 8.83(1 \mathrm{H}, \mathrm{d}, J=7.5 \mathrm{~Hz}), 11.78(1 \mathrm{H}$, s, NH), $13.09(1 \mathrm{H}, \mathrm{s}, \mathrm{NH})$. Due to its insolubility, the ${ }^{13} \mathrm{C}$ NMR spectrum could not be recorded.

4.1.16. 5H,6H,8H-1,3,4,7-Tetrahydrofurano-

[3,4-c]pyridazino[3,4-a]carbazole 18 and $2 \mathrm{H}, 5 \mathrm{H}, 6 \mathrm{H}$, 8H-2-amino-1,3,4,7-tetrahydropyridazino[3,4-a]pyrrolo-

[3,4-c]carbazole-1,3,4,7-tetraone 19

A solution of $17(150 \mathrm{mg}, 0.49 \mathrm{mmol})$ in hydrazine hydrate $(5 \mathrm{~mL})$ was stirred at $60{ }^{\circ} \mathrm{C}$ for $24 \mathrm{~h}$. Water $(150 \mathrm{~mL})$ was added, then $12 \mathrm{~N} \mathrm{HCl}(20 \mathrm{~mL})$ was added dropwise. After stirring for $30 \mathrm{~min}$ at $0{ }^{\circ} \mathrm{C}$, the precipitate was filtered off, and then washed with water and EtOAc to give 19 (60 mg, $0.18 \mathrm{mmol}, 37 \%$ yield) as an orange solid. The filtrate was evaporated to give 18 (5 mg, $0.016 \mathrm{mmol}, 3 \%$ yield) as a yellow solid.

4.1.16.1. Compound 18. $\mathrm{Mp}>280{ }^{\circ} \mathrm{C}$. IR $(\mathrm{KBr}) \nu_{\mathrm{C}=\mathrm{O}} 1720$, $1782 \mathrm{~cm}^{-1}, \nu_{\mathrm{NH}} 3411 \mathrm{~cm}^{-1}$. Mass (ESI +$)[\mathrm{M}+\mathrm{H}]^{+} 322 .{ }^{1} \mathrm{H}$ NMR $\left(400 \mathrm{MHz}\right.$, DMSO- $\left.d_{6}\right): 7.35\left(1 \mathrm{H}, \mathrm{dt}, J_{1}=7.0 \mathrm{~Hz}\right.$, $\left.J_{2}=1.0 \mathrm{~Hz}\right), 7.61\left(1 \mathrm{H}, \mathrm{dt}, J_{1}=8.0 \mathrm{~Hz}, J_{2}=1.0 \mathrm{~Hz}\right), 7.99$ $(1 \mathrm{H}, \mathrm{d}, J=8.0 \mathrm{~Hz}), 8.16(1 \mathrm{H}, \mathrm{d}, J=8.0 \mathrm{~Hz}), 11.90-12.60$ $(3 \mathrm{H}$, br s, NH).

4.1.16.2. Compound 19. $\mathrm{Mp}>300^{\circ} \mathrm{C}$. IR $(\mathrm{KBr}) \quad \nu_{\mathrm{C}=\mathrm{O}}$ $1736 \mathrm{~cm}^{-1}, \quad \nu_{\mathrm{N}=\mathrm{N}} 2173 \mathrm{~cm}^{-1}, \quad \nu_{\mathrm{NH}} 3445 \mathrm{~cm}^{-1}$. HRMS $(\mathrm{FAB}+)[\mathrm{M}+\mathrm{H}]^{+}$calcd for $\mathrm{C}_{16} \mathrm{H}_{10} \mathrm{~N}_{5} \mathrm{O}_{4}$ 336.0732, found 336.0730. ${ }^{1} \mathrm{H}$ NMR $\left(400 \mathrm{MHz}\right.$, DMSO- $\left.d_{6}\right): 5.30(2 \mathrm{H}, \mathrm{s}$, $\left.\mathrm{NH}_{2}\right), 7.52(1 \mathrm{H}, \mathrm{t}, J=7.5 \mathrm{~Hz}), 7.73(1 \mathrm{H}, \mathrm{t}, J=7.5 \mathrm{~Hz}), 8.07$ $(1 \mathrm{H}, \mathrm{d}, J=8.0 \mathrm{~Hz}), 8.99(1 \mathrm{H}, \mathrm{d}, J=8.0 \mathrm{~Hz}), 12.36(1 \mathrm{H}, \mathrm{s}$, $\mathrm{NH}), 12.46(1 \mathrm{H}, \mathrm{s}, \mathrm{NH}), 12.90(1 \mathrm{H}, \mathrm{s}, \mathrm{NH}),{ }^{13} \mathrm{C} \mathrm{NMR}$ $\left(100 \mathrm{MHz}\right.$, DMSO- $\left.d_{6}\right)$ : 113.2, 115.1, 118.8, 119.1, 119.2, 128.4, 141.4, 142.4 (C quat arom), 113.7, 121.9, 124.6, $129.3(\mathrm{C}$ tert arom $), 148.5,158.1,166.5,171.5(\mathrm{C}=\mathrm{O})$.

\subsection{Kinase inhibition assays}

Chklinhibition assays: Human Chk1 full-length enzyme with an N-terminal GST sequence was either purchased 
from Upstate Biochemicals (No. 14-346) or purified from extracts of Sf9 cells infected with a baculovirus encoding GSTChk1. Assays for compound testing were based upon the method described by Davies et al. [26].

Src inhibition assays: Inhibitors were diluted with a Tecan Evo150 robot. The kinase assay was performed with $4 \mu \mathrm{L}$ of inhibitor (10\% dimethylsulfoxide (DMSO)), $10 \mu \mathrm{L}$ of kinase assay buffer $4 \times$ concentrated $\left(80 \mathrm{mM} \mathrm{MgCl}_{2}, 200 \mathrm{mM} 4-(2-\right.$ hydroxyethyl)-1-piperazineethanesulfonic acid (HEPES), $0.4 \mathrm{mM}$ ethylenediaminetetraacetic acid (EDTA), $2 \mathrm{mM}$ DL-dithiothreitol (DTT)), $10 \mu \mathrm{L}$ substrate peptide (KVEKIGEGYYGVVYK, $370 \mathrm{nM}$ ) and $6 \mu \mathrm{L}$ Src kinase (stock GTP purified diluted with $1 \times$ kinase assay buffer to $200 \mathrm{nM}$ ). $10 \mu \mathrm{L}$ co-substrate $\left(40 \mu \mathrm{M}\right.$ ATP with $0.2 \mu \mathrm{Ci} \mathrm{P}^{33}-\gamma$-ATP $)$ was added with a Precision 2000 (Biotek Robotic). The assay was incubated $20 \mathrm{~min}$ at $30^{\circ} \mathrm{C}$ then stopped by adding $200 \mu \mathrm{L}$ $0.85 \%$ orthophosphoric acid, then transferred to a phosphocellulose filter microplate (Whatman - P81). The plate was washed three times with $200 \mu \mathrm{L} 0.85 \%$ orthophosphoric acid and dried with $200 \mu \mathrm{L}$ acetone. The remaining activity was measured on a Topcount with $25 \mu \mathrm{L}$ scintillation solution (Packard UltimaGold).

\subsection{Molecular modelling}

All molecular mechanics calculations were performed by the Macromodel [27] molecular modelling software. We used as model the complex structure of Chk1/staurosporine [10] downloaded from the Protein Data Bank (1NVR file).

Energy minimisation was done with AMBER force field $[28,29]$ using the Truncated Newton Conjugate Gradient method (TNCG).

\subsection{Growth inhibition assays}

Tumor cells were provided by American Type Culture Collection (Frederik, MD, USA). They were cultivated in RPMI 1640 medium (Life Science technologies, Cergy-Pontoise, France) supplemented with $10 \%$ fetal calf serum, 2 mM L-glutamine, 100 units $/ \mathrm{mL}$ penicillin, $100 \mu \mathrm{g} / \mathrm{mL}$ streptomycin, and $10 \mathrm{mM}$ HEPES buffer $(\mathrm{pH}=7.4)$. Cytotoxicity was measured by the microculture tetrazolium assay as described [30]. Cells were continuously exposed to graded concentrations of the compounds for four doubling times, then $15 \mu \mathrm{L}$ of $5 \mathrm{mg} / \mathrm{mL}$ 3-(4,5-dimethylthiazol-2-yl)-2,5-diphenyltetrazolium bromide were added to each well and the plates were incubated for $4 \mathrm{~h}$ at $37^{\circ} \mathrm{C}$. The medium was then aspirated and the formazan solubilized by $100 \mu \mathrm{L}$ of DMSO. Results are expressed as $\mathrm{IC}_{50}$, concentration which reduced by $50 \%$ the optical density of treated cells with respect to untreated controls.

\section{Acknowledgement}

The authors are grateful to Bertrand Légeret, University Blaise Pascal, Clermont-Ferrand, for recording the mass spectra.

\section{References}

[1] H.J. Anderson, R.J. Andersen, M. Roberge, in: L. Meijer, A. Jézéquel, M. Roberge (Eds.), Prog. Cell Cycle Res., 5, 2003, pp. 423-430.

[2] M. Prudhomme, Recent Pat. Anti-Cancer Drug Discovery 1 (2006) 55-68.

[3] J. Bartek, J. Lukas, Cancer Cell 3 (2003) 421-429.

[4] Z.F. Tao, Anticancer Agents Med. Chem. 6 (2006) 377-388.

[5] R.G.S. Berlinck, R. Britton, E. Piers, L.Y. Lim, M. Roberge, R. Moreira da Rocha, R.J. Andersen, J. Org. Chem. 63 (1998) 9850-9856.

[6] M. Roberge, R.G.S. Berlinck, L. Xu, H.J. Anderson, L.Y. Lim, D. Curman, C.M. Stringer, S.H. Friend, P. Davies, I. Vincent, S.J. Haggarty, M.T. Kelly, R. Britton, E. Piers, R.J. Andersen, Cancer Res. 58 (1998) 5701-5706.

[7] R.J. Andersen, M. Roberge, J. Sanghera, D. Leung, PCT. Int. Appl. WO99/47522, 1999. Chem. Abstr. 131:243451.

[8] X. Jiang, B. Zhao, R. Britton, L.Y. Lim, D. Leong, J.S. Sanghera, B.B.S. Zhou, E. Piers, R.J. Andersen, M. Roberge, Mol. Cancer Ther. 3 (2004) 1221-1227.

[9] E. Piers, R. Britton, R.J. Andersen, J. Org. Chem. 65 (2000) 530-535.

[10] B. Zhao, M.J. Bower, P.J. McDevitt, H. Zhao, S.T. Davis, K.O. Johanson, S.M. Green, N.O. Concha, B.B.S. Zhou, J. Biol. Chem. 277 (2002) 46609-46615.

[11] B. Hugon, B. Pfeiffer, P. Renard, M. Prudhomme, Tetrahedron Lett. 44 (2003) 3935-3937.

[12] B. Hugon, B. Pfeiffer, P. Renard, M. Prudhomme, Tetrahedron Lett. 44 (2003) 3927-3930.

[13] H. Hénon, S. Messaoudi, B. Hugon, F. Anizon, B. Pfeiffer, M. Prudhomme, Tetrahedron 61 (2005) 5599-5614.

[14] H. Hénon, F. Anizon, B. Pfeiffer, M. Prudhomme, Tetrahedron 62 (2006) 1116-1123.

[15] H. Hénon, F. Anizon, N. Kucharczyk, A. Loynel, P. Casara, B. Pfeiffer, M. Prudhomme, Synthesis 4 (2006) 711-715.

[16] H. Hénon, F. Anizon, R.M. Golsteyn, S. Léonce, R. Hofmann, B. Pfeiffer, M. Prudhomme, Bioorg. Med. Chem. 14 (2006) 38253834.

[17] H. Hénon, F. Anizon, B. Aboab, N. Kucharczyk, S. Léonce, R.M. Golsteyn, B. Pfeiffer, M. Prudhomme, Eur. J. Pharmacol. 554 (2007) 106-112.

[18] E. Conchon, F. Anizon, R. Golsteyn, S. Léonce, B. Pfeiffer, M. Prudhomme, Tetrahedron 62 (2006) 11136-11144.

[19] E. Conchon, B. Aboab, R. Golsteyn, S. Léonce, B. Pfeiffer, M. Prudhomme, Eur. J. Med. Chem. 41 (2006) 1470-1477.

[20] H.J. Knölker, R. Hitzemann, Tetrahedron Lett. 35 (1994) 2157-2160.

[21] E. Wenkert, P.D.R. Moeller, S.R. Piettre, J. Am. Chem. Soc. 110 (1988) 7188-7194.

[22] C. Bailly, X. Qu, F. Anizon, M. Prudhomme, J.F. Riou, J.B. Chaires, Mol. Pharmacol. 55 (1999) 377-385.

[23] E. Rodrigues Pereira, S. Fabre, M. Sancelme, M. Prudhomme, M. Rapp, J. Antibiot. 48 (1995) 863-868.

[24] (a) E. Rodrigues Pereira, L. Belin, M. Sancelme, M. Prudhomme, M. Ollier, M. Rapp, D. Sevère, J.F. Riou, D. Fabbro, T. Meyer, J. Med. Chem. 39 (1996) 4471-4477;

(b) F. Anizon, PhD thesis, Université de Clermont-Ferrand, France, DU No $1162,1999$.

[25] See Belstein 24, 373.

[26] S.P. Davies, H. Reddy, M. Caivano, P. Cohen, Biochem. J. 351 (2000) 95-105.

[27] Macromodel 8.0, Shroedinger Inc, 1500 SW First Ave. Suite 1180, Portland, OR 97201, USA.

[28] S.J. Weiner, P.A. Kollman, A.D. Case, U.C. Singh, C. Ghio, G. Alagona, S. Profeta, P. Weiner, J. Am. Chem. Soc. 106 (1984) 765-784.

[29] W.D. Cornell, P. Cieplak, C.I. Bayly, I.R. Gould, K.M. Merz, D.M. Ferguson, D.C. Spellmeyer, T. Fox, J.M. Caldwell, P.A. Kollman, J. Am. Chem. Soc. 117 (1995) 5179-5197.

[30] S. Léonce, V. Pérez, M.R. Casabianca-Pignède, M. Anstett, E. Bisagni, G. Atassi, Invest. New Drugs 14 (1996) 169-180. 